\title{
Manipulated Mesenchymal Stem Cells Applications in Neurodegenerative Diseases
}

\author{
Seyyed omid Sadatpoor ${ }^{1}$, Zahra Salehi ${ }^{2}$, Dariush Rahban ${ }^{3}$, Ali Salimi ${ }^{1}$ \\ ${ }^{1}$ Nanobiotechnology Research Center, Baqiyatallah University of Medical Sciences, Tehran, Iran \\ ${ }^{2}$ Immunology Department, School of Medicine, Tehran University of Medical Sciences, Tehran, Iran \\ ${ }^{3}$ Department of Nanomedicine, School of Advanced Medical Technologies, Tehran University of Medical Science, Tehran, Iran
}

Mesenchymal stem cells (MSCs) are multipotent stem cells that have multilinear differentiation and self-renewal abilities. These cells are immune-privileged as they express no or low level of class-II major histocompatibility complex (MHC-II) and other costimulatory molecules. Having neuroprotective and regenerative properties, MSCs can be used to ameliorate several intractable neurodegenerative disorders by affecting both innate and adaptive immune systems. Several manipulations like pretreating MSCs with different conditions or agents, and using molecules derived from MSCs or genetically manipulating them, are the common and practical ways that can be used to strengthen MSCs survival and potency. Improved MSCs can have significantly enhanced impacts on diseases compared to MSCs not manipulated. In this review, we describe some of the most important manipulations that have been exerted on MSCs to improve their therapeutic functions and their applications in ameliorating three prevalent neurodegenerative diseases including Alzheimer's disease, Parkinson's disease, and Huntington's disease.

Keywords: Mesenchymal stem cells, Neurodegenerative diseases, MSCs manipulation

\section{Introduction}

Mesenchymal stem cells (MSCs) are spindle-shaped multipotent non-hematopoietic adult stem cells, first characterized by Friedenstein et al., in 1974 (1). MSCs originate from the mesoderm, possess extensive proliferative and self- renewal potential with the ability to attach to plastic and gather in colonies called colony form-

Received: February 27, 2019, Revised: April 7, 2019,

Accepted: April 13, 2019, Published online: February 29, 2020

Correspondence to Ali Salimi

Nanobiotechnology Research Center, Baqiyatallah University of Medical Sciences, Tehran 19395, Iran

Tel: +98-912-859-7580, Fax: +98-21-88600030

E-mail: Salimiali@bmsu.ac.ir

(c) This is an open-access article distributed under the terms of the Creative Commons Attribution Non-Commercial License (http://creativecommons.org/ licenses/by-nc/4.0/), which permits unrestricted non-commercial use, distribution, and reproduction in any medium, provided the original work is properly cited.

Copyright (C) 2020 by the Korean Society for Stem Cell Research ing units (CFUs) (2). MSCs are immune-privileged because of the lack or low expression of class-II major histocompatibility complex (MHC-II) and other costimulatory molecules $(3,4)$. Nowadays, it has been shown that MSCs can be established by differentiation of pluripotent stem cells like embryonic stem cells (ESCs) and induced pluripotent stem cells (iPSCs). The pluripotent stem cells-derived MSCs (PSCs- MSCs) have presented better self-renewal capability, engraftment efficacy and higher therapeutic potency than MSCs derived from adult tissues. The PSCs derived-MSCs replace damaged cells in injured tissues, exert immunomodulatory effects, release matrix proteins and growth factors that eventually adjusts the surroundings of damaged tissues. These PSCs-MSCs are evidently useful in regenerative medicine to treat a number of unmanageable immunological and neurological disorders $(5,6)$.

MSCs are found in multiple tissues, including bone marrow (BM-MSCs), umbilical cord blood (UCB-MSCs), umbilical cord (UC-MSCs), placenta (PL-MSCs), adipose 
tissue (AT-MSCs), fetal liver, muscle, lung, and heart which differs in their biological characteristics (7). MSCs have the ability to differentiate into cells of the mesodermal lineage (adipocytes, chondrocytes, osteoblasts, osteocytes, and myoblasts). However, few studies have also shown the ability of differentiation into ectodermic (neuronlike cells) and endodermic (hepatocytes) cell lineages (8, 9).

Although conflicting results have been reported, MSCs can be recognized according to the expression of a universal panel of cellular markers proposed by the International Society for Cell Therapy (ISCT). Using antibody-based classification methods, minimal criteria for defining human MSCs included positive expression of CD44, CD73 (SH3), CD90 and CD105, and negative expression of CD45, CD34, CD14, CD79a and HLA-DR (10). Additionally, using high-throughput techniques, transmembrane 4 L6 family member 1 (TM4SF1) have been proved effective as MSC-specific surface marker (11).

Since no available data have shown detrimental reactions to allogeneic or autologous MSCs transplants, these cells are great candidates for cell-therapy $(12,13)$. Furthermore, being more available, free from ethical issues, easy to isolate and expand, able to differentiate to multiple lineages and immunosuppressive, have made MSCs better candidates than embryonic stem cells (ESCs) and induced pluripotent stem cells (iPSCs) (14). Consequently, MSCs are considered to be safe as they are tested in many clinical trials of neurodegenerative, immunological and also cardiovascular diseases, which have had promising results $(13,15,16)$.

Neurological diseases cause a huge burden on global health and their occurrence is growing in low and middle-income countries $(17,18)$. Numerous factors, including genetic and environmental components, may involve in the development and progression of this kind of diseases (19). The term "neurodegenerative diseases" consists of a lot of diseases like Alzheimer's disease, Parkinson's disease, and Huntington's disease (19-21). Aggregation of insoluble forms of abnormal proteins between central nervous system (CNS) cells is a pathological characteristic seen in almost all of neurodegenerative diseases $(22,23)$. Following disease progression, CNS degrades gradually and neuronal functions and structures are lost (24). Our aim in this review is to summarize the most important manipulation methods that can be utilized to enhance MSCs survival and potency and their applications in treating the most prevalent neurodegenerative diseases.

\section{Immunomodulatory, Neuroprotective and Regenerative Capacities of MSCs}

Having the unique capacity to modulate immune cells $(25,26)$, MSCs are exclusive target for immunomodulation purposes $(27,28)$. The point that these cells are almost non-immunogenic rises from the fact that MSCs only express human leukocyte antigen-I (HLA-I) and lack HLA-II and other costimulatory molecules like CD80 and CD86, needed for $\mathrm{T}$ cell activation $(27,29)$. Although MSCs from different sources exert their immunomodulatory functions in different ways, the fundamental mechanism is shared among them. Both cell-cell contact and secreted molecules are involved in immunomodulatory properties mediated by MSCs $(25,30,31)$.

Considering inflammatory responses as an inseparable part of neurological diseases, MSCs have shown themselves as a promising therapeutic approach for treatment of some of these unmanageable neurological disorders. Notably, neuroprotective and regenerative effects of MSCs results from their immunomodulatory and anti-inflammatory potential. Neuroprotection and therapeutic effects of MSCs in experimental CNS disease models have been shown in various studies. One of these researches unveiled the neuroprotective effects of AT-MSCs in models of Parkinson's disease $(32,33)$. Similarly, regenerative capabilities of MSCs have been shown in experimental rats where administration of MSCs derived from dental pulps enhanced both motor nerve regeneration and behavioral activities (34). MSCs have the ability to secrete various growth factors, making the damaged tissue microenvironment ready for regeneration and tissue repair. For instance, insulin growth factor binding protein 6 (IGF BP-6) secreted by MSCs improves recovery from nerve injury in H2O2-injured cortical neuron cultures through inhibiting IGF-2 and interacting with insulin growth factor 1 receptor (IGF-1R) (35). In addition, hypoxic-ischemic brain damage (HIBD) is a prevalent cause of newborn death. Using PL-MSCs as a treatment in this situation prevented the production of pro-inflammatory cytokines and enhanced the production of IL-10 in the ischemic hemispheres of HIBD rats (36). On the other hand, in a rodent stroke model, it has been shown that intravenous injection of UC-MSCs improved functional losses and decreased neuronal damage (37). Suppressing inflammatory responses is the main effect of PL-MSCs and UC-MSCs for attenuating HIBD and relieving stroke effects, respectively $(36,37)$.

Since the therapeutic properties of MSCs are mainly exerted by affecting both innate and adaptive immune re- 
sponses (38), hereby we discuss the most important immunomodulatory effects exerted by MSCs on immune cells.

\section{Antigen-presenting cells}

Antigen-presenting cells (APCs) include dendritic cells, macrophages and $\mathrm{B}$ cells that process and present antigens to $\mathrm{T}$ cells. Since DCs initiate immune responses via presenting antigens to naïve $\mathrm{T}$ cells, they appear to be more important $(25,39)$. MSCs inhibit monocytes from differentiation into DCs in the periphery which results into lesser induction of $\mathrm{T}$ cell response and cause M2 macrophage differentiation $(27,40,41)$. The major soluble factors implicated in these events are prostaglandin E2 (PGE2), Interleukin 6 (IL-6), and macrophage colonystimulating factor (M-CSF) (25). Different studies have been conducted to elucidate the mechanisms by which MSCs inhibit the maturation and function of the DCs. In a coculture system of BM-MSCS and DCs it has been shown that: (1) overexpression of microRNA-23b (miR23b) in MSCs inhibited DCs maturation by blocking the NF- $\kappa$ B pathway (42); (2) concentrations of galectin-1 (Gal-1), IL-10, and IL-12 were increased in the supernatants and the protein expression of Gal-1 on and within MSCs was also enhanced which hampered the function of DCs (43).

\section{Natural killer cells}

Natural killer cells play an important role in cell innate immunity against tumor and virus-infected cells. MSCs can significantly reduce the proliferation and activation of NK cells through direct cell contact and also soluble factors like indoleamine 2,3-dioxygenase (IDO) and PGE2 production. The secretion of sHLAG5 by MSCs lessen NK cells cytolytic activity and IFN- $\gamma$ production of these cells $(25,44,45)$. In addition, MSCs have been demonstrated to reduce the secretion of IFN- $\gamma$ and TNF- $\alpha$ by NK cells.

It is known that NK cells can kill cells by detecting the lack of HLA-I molecules on target cells. Prominently, expression of HLA-I molecules on the surface of MSCs makes them resistant to lysis by NK cells. The HLA-I expression on MSCs is even amplified when the cells are pretreated by IFN- $\gamma$, used for strengthening the anti-inflammatory effects of MSCs $(27,46)$.

\section{T cells}

$\mathrm{T}$ lymphocytes, predominantly produced in the thymus, are mainly involved in cellular immune response. It is well defined that MSCs inhibit T cells proliferation more than
$50 \%(29,47)$. BM-MSCs and UCB-MSCs cause the arrest of $\mathrm{T}$ cell cycle while AT-MSCs and UC-MSCs induce apoptosis to inhibit $\mathrm{T}$ cell proliferation. BM-MSCs reduce Thelper1 (Th1) and Th17 cells-derived cytokines and also cause upregulation of the anti-inflammatory cytokines production such as IL-4 from Th2 cells. The expression of inhibitory molecules like PDL1 and PDL2 or HLA-G, expressed by all PL-MSCs and also the lack of costimulatory molecules on MSCs led to T cells anergy. Further, MSCs cause Treg cells proliferation which can be enhanced by priming MSCs in hypoxia, as hypoxia increases the expression of IDO.

\section{B cells}

B lymphocytes are another component of the adaptive immune system which has important roles in the initiation and progression of many diseases, mostly by secreting antibodies (48). MSCs can be really effective in ameliorating these effects as they cause decreased B cell proliferation, differentiation, chemotactic properties and antibodysecreting ability (49-52). On the other hand, MSCs lead to augmentation of B lymphocytes viability. For instance, placental MSCs interfere with B cells apoptosis (Fig. 1) (40).

\section{Manipulation of MSCs}

To improve therapeutic characteristics, MSCs can be manipulated by different approaches. They can be pretreated with various chemical, physical and biological agents, and modified with varied genetic and/or epigenetic manipulations to enhance their functions, efficacy and safety of transplantation (53-55).

\section{Pretreatment (preconditioning) of MSCs}

MSC source: MSCs can be isolated from many adult and fetal tissues. However, MSCs from diverse origins have various characteristics. This offers that sources of MSCs may have an impact on their cellular destiny and behavior. Briefly, the overall orientation considering MSCs origin can be expressed as follows: (a) MSCs derived from a certain origin can differentiate better to cells of that tissue than other MSCs (BM-MSCs have better osteogenesis capacity than the others); (b) fetal MSCs, mainly, have a higher proliferation capacity than adult MSCs; (c) if the immunomodulatory effects are substantial, fetal MSCs or AT-MSCs are better options than BM-MSCs. (d) Overall, AT-MSCs reveal great in vivo capability for cell therapy $(56,57)$.

Hypoxia preconditioning: Typically, the oxygen con- 


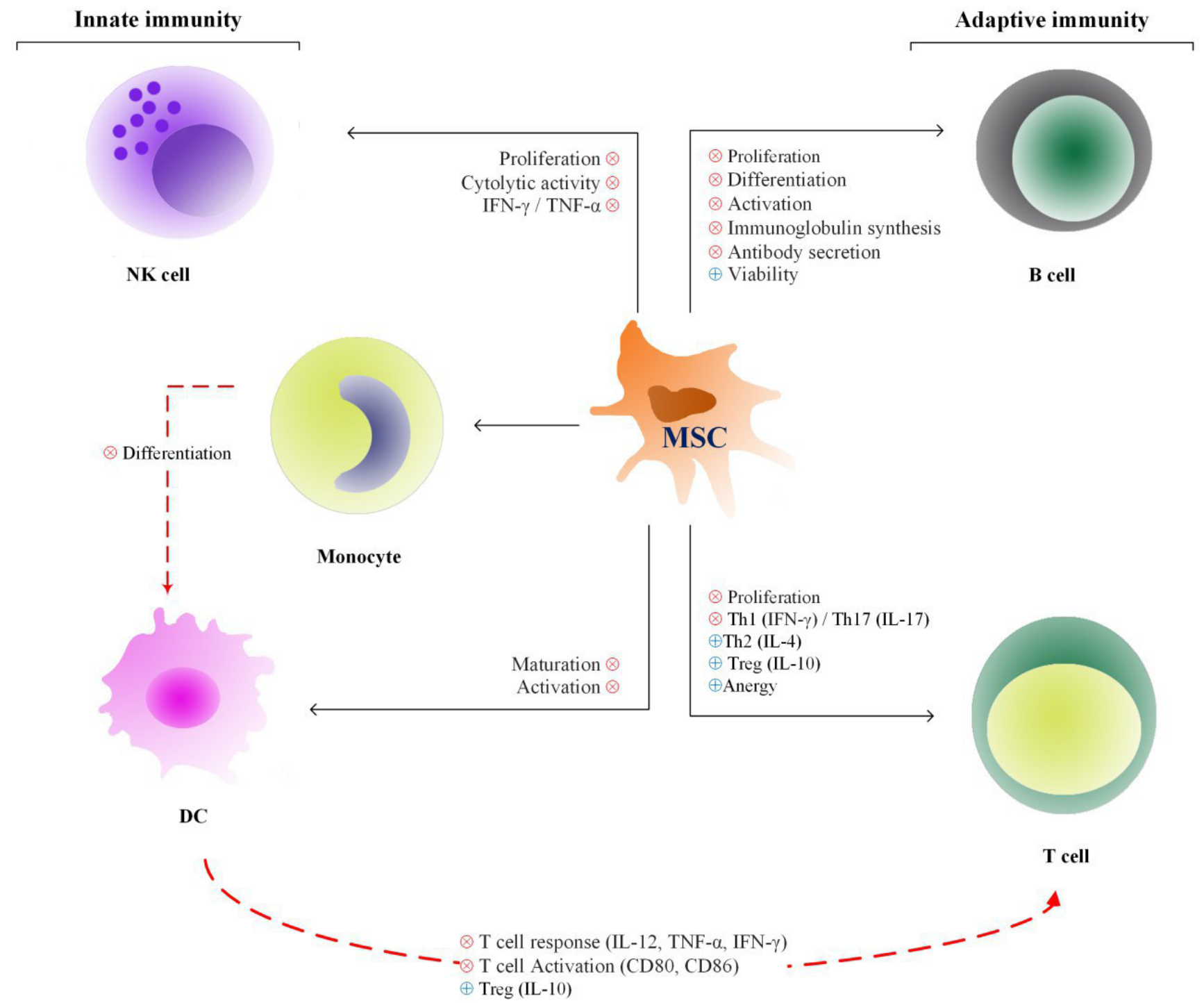

Fig. 1. MSCs immunomodulatory effects on immune cells. MSCs have inhibitory effects on both innate and adaptive immunity. Their immunomodulatory impacts which are conducted by secretion of soluble factors and cell to cell contact include: (1) inhibition of B and NK cells proliferation and functions; (2) suppression of T cells proliferation and Th1 differentiation, induction of TH2 and Treg cells; (3) inhibition of dendritic cell and monocyte maturation and activation.

centration in MSC niches is rather low. A number of studies have shown that MSCs may be influenced by greater oxygen concentrations in ex vivo culture and their viability decreased $(54,58)$. Therefore, it seems that hypoxia preconditioning of MSCs, before using them in different therapeutical applications, is a suitable method to prepare them to face and endure difficult situations. Hypoxia preconditioning is applied by culturing MSCs at $2.5 \% \mathrm{O} 2$ (for 15 minutes) and reoxygenation at $21 \%$ O2 (for $30 \mathrm{mi}$ nutes) which is followed again by hypoxia preconditioning at $2.5 \% \mathrm{O} 2$ (for 72 hours) $(59,60)$. The process of hypoxia and reoxygenation enhances the expression of pro-survival genes $(55,61)$.

In fact, when MSCs are cultured with 1 7\% O2, they are preconditioned by hypoxia and this manipulation enhances different aspects of MSCs characteristics (55). Hypoxia improves proliferation and migration of MSCs, and also causes lower expression of senescence-associated molecules like caspase- 3 and $\beta$-galactosidase in these cells (54). Moreover, by improving the secretion of anti-inflammatory cytokines and other soluble factors, hypoxia pretreatment increases immunosuppressive characteristics 
of MSCs. For instance, human gingiva-derived MSCs produced more IL-10 and express more "Fas ligand (FasL)" when they were exposed to hypoxia. As well, human AT-MSCs pretreated with hypoxia showed upregulated IDO expression, causing T cell anergy, Treg generation, and increased IL-10 production $(60,62,63)$. Hypoxic pretreatment makes hypoxia-inducible factor-1 $\alpha$ (HIF-1 $\alpha$ ) more stable (54). HIF-1 $\alpha$ reduces reactive oxygen species (ROS) production, promotes glycolysis (54) and induces expression of $78-\mathrm{kDa}$ glucose-regulated protein (GRP78) which enhances cell proliferation through Akt pathway. After $12 \mathrm{~h}$ of hypoxia, GRP78-mediated phosphorylation of Akt, mTOR, and P70S6k (ribosomal protein S6 kinase $\beta$-1) was increased. GRP78 also increases cell cycle-associated proteins such as CDK2, cyclin E, CDK4, cyclin D1 through the regulation of Akt signaling pathway (64). HIF-1 $\alpha$ activates nuclear factor kappa B $(\mathrm{NF}-\kappa \mathrm{B})$, increase antioxidant and antiapoptotic proteins like Bcl-xl and Bcl-2 (54). Hypoxia preconditioning of MSCs also upregulates the expression of normal cellular prion protein ( $\mathrm{PrPc}$ ), which regulates superoxide dismutase (SOD) and catalase activity and hampers oxidative stress-induced apoptosis by inactivation of cleaved caspase3 $(54,65)$.

Nutrient deprivation: MSCs confront an ischemic microenvironment, recognized by reduced oxygen (O2) tension (hypoxia) and nutrient deprivation (serum or glucose starvation) concurrently, that may threaten survival of the MSCs, especially in tissue engineering. Human MSCs were exposed to (I) $\mathrm{O} 2$ deprivation (hypoxia), (II) serum starvation (for 48 hours), and (III) prolonged (up to 120 hours) hypoxia associated with serum deprivation (ischemia). As a result, the MSC apoptosis rates were not influenced by 48-hour hypoxia, but elevated through fetal bovine serum (FBS) starvation, indicating that nutrient deprivation is the stronger factor than hypoxia (66). Long-term hypoxia along with serum starvation bring almost complete apoptosis of MSCs, but this rate was decreased by half when MSCs were encountered hypoxia and $10 \%$ FBS. This finding shows that MSCs are susceptible to the concurrent serum and $\mathrm{O} 2$ deprivation which they face when transplanted in vivo (67). It evokes the development of new methods in cell therapy by MSCs.

Pretreatment of MSCs with cytokines: Cytokines affect interactions and communications between variouse cells. Likewise, MSCs are no exception to this fact and considerable work have been done to elucidate these effects. In comparison to others, proinflammatory cytokines like IFN- $\gamma$, TNF- $\alpha$, and IL-1 $\beta$ exert more modulatory effects on MSCs (68).
Pretreating MSCs with IFN- $\gamma$ enhances the production of PGE2 and IDO (responsible for the suppression of $\mathrm{T}$ and NK cells proliferation). These MSCs inhibit NK cells activation and cytotoxicity and block production of Th1related cytokines (IFN- $\gamma$, TNF- $\alpha$, and IL-1) $(55,60)$. TNF- $\alpha$ activates Erk1/2 and MAPK signaling pathway and causes increased proliferation and osteogenic differentiation of MSCs (55). Modulatory effects of TNF- $\alpha$ are seen more when MSCs are pretreated with both of IFN- $\gamma$ and TNF- $\alpha$. This combination increases the production of IDO, PGE2, PDL-1, and HLA-G. IDO and PGE2 are important in the secretion of factor $\mathrm{H}$, a complement system inhibitor. $\mathrm{CD}_{206^{+}} \mathrm{M} 2$ macrophages are generated from $\mathrm{CD}_{14}{ }^{+}$monocytes to suppress PBMCs proliferation. Alongside $\mathrm{M} 2$ macrophage generation, both cytokines result in enhanced PDL-2 expression by MSCs and CD4 ${ }^{+} \mathrm{IL}_{-10}{ }^{+}$ and $\mathrm{CD}^{+}{ }^{+} \mathrm{IL}-10^{+}$Treg cells differentiation. IFN- $\gamma$ and TNF- $\alpha$ have the ability to induce the production of proinflammatory chemokines such as CCL5, CXCL9, CXCL10, CXCL11 through MSCs. These chemokines accumulate immune cells in close proximity to MSCs in order to lay them more exposed to MSCs immunosuppressive effects (55, 60, $69,70)$.

IL-1 $\beta$-treated MSCs show significant immunomodulatory properties such as enhanced migratory abilities through the increased expression of CXCR4 and other related chemokines. Production of several chemokines is another immunomodulatory influence of MSCs enhanced by IL-1 $\beta$, resembling TNF- $\alpha$ effect. It can also cause MSCs to produce certain cytokines that can regulate the function of target cells $(60,71,72)$.

Additionally, IL-17A-treated MSCs, cocultured with $\mathrm{CD} 4{ }^{+} \mathrm{CD} 25^{-} \mathrm{T}$ cells, are able to increase $\mathrm{CD} 4{ }^{+} \mathrm{CD} 25^{\mathrm{hi}}$ $\mathrm{CD} 127^{\mathrm{lo}} \mathrm{FoxP}^{+}$Tregs (60). IFN- $\alpha$-preconditioned MSCs also show increased migratory potential and they also inhibit Th1 inflammatory responses $(55,73)$. Stromal-derived factor-1 (SDF-1), known as CXCL12, is a chemokine used for MSCs preconditioning. This chemokine enhances the production of angiogenic cytokines through activation of Akt and Erk signaling pathways. SDF-1 rescues MSCs from H2O2-induced apoptosis which is followed by increased migration and survival rate of $\operatorname{MSCs}(55,74)$.

Pharmacological and clinical drugs: Mesenchymal stem cell-based therapy is a great choice for treating CNS diseases, although loss of the cells after transplantations remains a serious setback. Exposure of MSCs to different pharmacological agents is another preconditioning method for strengthening their survival when they encounter the harsh microenvironment of the damaged tissue (75, 76). 
Atorvastatin (C33H35FN2O5), a lipid-lowering statin, commonly used to prevent cardiovascular-related diseases. When used as a preconditioning agent, it can improve post-implantation survival of MSCs (77). This drug increases surface expression of CXCR4 in MSCs and stimulates migratory abilities of these cells by CXCR4/SDF-1 involvement (78).

Trimetazidine $(\mathrm{C} 14 \mathrm{H} 22 \mathrm{~N} 2 \mathrm{O} 3)$ is an anti-ischemic drug used for treating angina in cardiac patients. In comparison to non-conditioned cells, Trimetazidine-preconditioned rat MSCs showed both notable protection against H2O2-induced membrane damage and increased viability. This drug increases HIF-1 $\alpha$, survivin, $\mathrm{BCl}-2$ gene expressions in MSCs (79).

Preconditioning of MSCs with deferoxamine (DFX); an iron-chelating drug, stabilizes HIF-1 $\alpha$ and enhances the expression of genes involved in cell migration. Deferoxamine also affects the homing of MSCs by enhancing the expression of chemokine receptors (77). Adipose tissue-derived-MSCs preconditioned with $150 \sim 400 \mu \mathrm{M}$ of DFX showed upregulated mRNA levels of pro-angiogenic factors; like vascular endothelial growth factor (VEGF), neuroprotective factors; such as nerve growth factor, neurotrophin 3, and anti-inflammatory cytokines (i.e. IL-4 and IL-5) (80).

Following pretreatment with LPS, an endotoxin in the cell wall of gram-negative bacteria, it binds to TLR4 on MSCs, activates PI3K/Akt pathway and increases expression of neural epidermal growth factor (NEGF). The problem of using unpreconditioned MSCs for infarcted myocardium is the low survival of these cells. Pretreatment of MSCs with $1 \mu \mathrm{g} / \mathrm{ml}$ and then transplantation of these cells into ischemic myocardium yielded increased survival and cardiac protective capacity of MSCs. For that reason, MSC pretreatment with LPS ameliorates cardiac function after myocardial infarction $(77,81)$.

Curcumin, the active part of turmeric and diazoxide which is a mitochondrial ATP-sensitive potassium channel, protect MSCs from oxidative stress injury $(82,83)$. Lithium and valproic acid (VPA)-preconditioned MSCs indicate enhanced expression of different genes like antioxidant, anti-apoptosis, and migration-related genes. The increased expression of these genes causes augmented survival of MSCs following transplantation (75).

In addition, vitamins also could be used for pretreating of MSCs. Vitamin E, a representative of vitamins, decrease both oxidative stress caused by $\mathrm{H} 2 \mathrm{O} 2$ and apoptosis-related in MSCs. This vitamin also enhances the expression of proliferative markers and TGF- $\beta(55,84)$.

Heat shock pretreatment (HSP) of MSCs: Heat shock pretreatment is an efficient method for elevating antiapoptotic properties of MSCs. It has been reported that HSP pretreatment lessens apoptosis of MSCs and enhance their survival in the injured tissue, especially heart, liver and ovary, by induction of autophagy. However, no research studies have been conducted on HSP pretreatment for MSCs application in a wide range of diseases $(85,86)$.

MSCs pretreatment by freeze and thaw (cryopreserved MSCs): The efficacy of MSCs therapy will be determined by a great part according to the phenotype of MSC after preparations. Cells can sustain considerable changes in response to alterations in their microenvironment. Freeze and thaw, as one of these changes, has been demonstrated to affect the immunomodulatory properties of MSCs. However, MSC functions are entirely revived after a $24 \mathrm{~h}$ culture period. After thawing, there were alterations in the genes involved in innate immunity pathways and in cytoskeletal rearrangement. Furthermore, thawed MSCs are vulnerable to $\mathrm{T}$ cell mediated cytotoxicity but this phenomenon is partially saved by IFN- $\gamma$ pre-licensing in MSCs $(87,88)$.

\section{Cell-free therapy}

MSCs cultured in different medium have been shown to secrete different factors referred to as MSCs conditioned medium, the secreted agents in the medium from MSCs as a whole, and microvesicles, exosomes and apoptotic bodies as well (89).

Conditioned medium of MSCs: Mesenchymal stem cells secrete different soluble factors into the culture medium. These secreted factors are referred to as conditioned media (CM), composed of growth factors like VEGF, epidermal growth factor (EGF), platelet-derived growth factor (PDGF), insulin-like growth factor (IGF-1), hepatocyte growth factor (HGF), pro/anti-inflammatory cytokines and other molecules like Leptin, angiogenin, granulocyte-macrophage colony-stimulating factor (GMCSF), fractalkine, monocyte chemoattractant protein-1 (MCP-1), SDF-1/CXCL12. Mesenchymal stem cells from different sources produce variable amounts of conditioned medium depending on culture medium type, period of culture (16 hours to 5 days) and culture condition (monolayer or spheroid) $(89,90)$. MSC conditioned medium (MSC-CM) possess both differentiation capacity and therapeutic function. UC-MSCs-derived conditioned medium (UC-CM) is used for different clinical applications like wound healing, helping to induce apoptosis and differentiation. The conditioned medium has anti-fibrotic properties and regenerative abilities and can suppress the proteolytic system and ROS generation in muscle atrophied cells 
(91, 92).

Administration of MSCs-CM in a mouse model of neuropathic pain induced by PSL (partial sciatic nerve ligation) exhibited longer antinociceptive effect in comparison to gabapentin, which is conventional treatment of neuropathic pain. Conditioned media also decreased the levels of proinflammatory cytokines including IL-1 $\beta$, TNF- $\alpha$, and IL-6 while increasing IL-10 concentrations (93).

In autoimmune diseases like rheumatoid arthritis (RA), MSC-based therapies can also yield positive results. The use of conditioned medium in antigen-induced arthritis (AIA) significantly lessened knee swelling, cartilage loss, and some other pathological signs of AIA. It also inhibited TNF- $\alpha$ production and increased IL-10 production through enhancing Treg cell functions (94).

Administration of conditioned medium derived from MSCs showed significant therapeutic effects on the pulmonary ischemic situation and myocardial infarction (MI). Treatment of lung ischemia-reperfusion injury by $\mathrm{CM}$ reduced proinflammatory cytokines, infiltration of inflammatory cells and increased Tregs and M2-like macrophages in the site of injury (95). Three weeks after treating by MSCs-CM, MI pigs showed higher myocardial capillary density, decreased myocardial infarct size and better systolic and diastolic performance (96).

Oxidative stress affects cell survival and it is important to prevent its effects on the cells. Conditioned medium taken from MSCs alleviated injury of $\mathrm{H} 2 \mathrm{O} 2$-induced oxidative stress in hepatocyte cells, and decreased levels of miR-143, which is increased after oxidative stress. The conditioned medium also restored Bcl level and decreased Bax and BMF levels in hepatocytes (97). The use of conditioned medium as a cryoprotectant results in reduction of apoptosis level in $\mathrm{CD} 34^{+}$umbilical cord blood cells and protection of these cells from oxidative stress due to ROS generation (98).

MSCs-derived exosomes and microvesicles: Exosomes and microvesicles are two secreted vesicles released from MSCs along with apoptotic bodies (53). These extracellular vesicles are distinguished from each other by their size, flotation density on sucrose, lipid composition, protein cargo and biogenesis pathway (99).

Exosomes are molecules with bilayer membrane with 40 $100 \mathrm{~nm}$ diameter which is secreted by most of the cells. They contain lipids including cholesterol (mostly), sphingomyelin, ceramide, proteins, and nucleic acids. Certain cluster of differentiation markers including CD9, CD63 and CD81 and tumor susceptibility gene 101 (Tsg101) as well as MHC-I and II are expressed on exosomes $(53,100)$. They are generated from early endosomes or multivesi- cular bodies and are released through the fusion of the endosome with the cell surface in a P53-regulated exocytosis process. This process is dependent on cytoskeletal activation but independent of cellular calcium. These molecules can be released in almost all kinds of fluids like blood, CSF, urine, amniotic fluid, ascites, saliva, seminal fluid, and etc. There are several methods to obtain exosomes from MSC cultures. Ultracentrifugation and polymer-based precipitation kits are the most common methods $(53,101)$. Exosomes are enriched with numerous bioactive molecules like proteins, lipids, mRNAs, micro RNAs, genomic DNA, cDNA, and mitochondrial DNA. They also contain cytokines and growth factors with immunomodulatory effects, including TGF- $\beta$, IL-6, IL-10 and HGF (53). Exosomes contents are protected from the RNases and trypsin by its bilayer lipid membrane (100). These secreted exosomes are involved mostly in intercellular communication and transportation of genetic material unleashed by MSCs. They have the ability to interact with various cells in close proximity and make them show appropriate response. One of the very important roles of MSCs-derived exosomes is their ability to support maintenance of homeostasis within the tissue especially in the event of diseases $(53,99)$.

In almost various types of diseases, the usage of MSCs produce good results. However, considering some of the risks that could happen by the administration of MSCs, researchers are encouraged to regard different aspects of these cells. Since most of the effects of MSCs are exerted through their paracrine actions, exosomes have been a good candidate for cell free therapy. Some of the risks that could arise by using MSCs but won't happen by the use of exosomes are as follows: (1) Persistency of MSCs proliferation when the need is over, so it can cause ectopic tissues formation (100, 102-104) in liver diseases. Although administration of MSCs helps to regenerate hepatocytes and reduce liver inflammation, the risk of iatrogenic tumor formation and cellular rejection remain unsolved (105). (2) Because of the large cell size of MSCs, the intravenous injection could cause occlusion, and ossification and calcification in tissues which caused long-term safety concerns (100). Overall, MSCs-derived exosomes have shown promising therapeutic effects when used in different kinds of diseases like cardiovascular diseases, immune-mediated diseases, neurological diseases and tumor (53).

In neurological diseases, exosomes can help in the removal of unwanted stress proteins and amyloid fibril formation. Exosomes also participate in the release of $\beta$-amyloid in Alzheimer's disease $(100,106,107)$. The 
use of exosomes in a model of spinal cord injury (SCI) has attenuated lesions and enhanced functional recovery after SCI. Exosomes also have been shown to decrease gene expression of Bax (apoptotic agent) and proinflammatory cytokines (IL-1 $\beta$, IL-6, TNF- $\alpha$ ) and increase BCL-2 and IL-10 (108).

Exosomes and microvesicles obtained from MSCs protected mice against joint damage in the osteoarthritis model (OA) by increasing the expression of chondrocyte markers (Type II collagen and aggrecan), while decreasing inflammatory markers such as induced nitric oxide synthase (iNOS) (109). Furthermore, in an atopic dermatitis mouse model, the use of adipose tissue-derived MSC exosomes decreased pathological symptoms and clinical score of the disease (109).

Microvesicles like exosomes are nanosized $(100 \sim 1000 \mathrm{~nm})$, bi-lipid layered vesicles $(53,110)$. These vesicles are secreted out of MSCs through budding of plasma membrane in a $\mathrm{Ca}^{2+}$-dependent pathway. Microvesicles express ARF6, VCAMP3, phosphatidylserine, and lipid raft-associated molecules (tissue factor and flotillin) and they are also enriched with CD40. These secreted microvesicles transfer different components and information such as mRNAs, micro RNAs, and proteins among stem cells and tissues (111). Microvesicles can be regarded as a good alternative therapeutic vehicle to MSCs. One good property that make them good candidate for stem cell-based therapy is that repeated administration of these factors do not incite immune responses. However, large-scale production of microvesicles and their long-term safety are issues that should be taken into consideration before using them as regenerative agents $(100,111)$.

Microvesicles can cause deviations in $\mathrm{T}$ cells differentiation, increase Th2 and regulatory $\mathrm{T}$ cell subsets. They can also augment apoptosis level in PBMCs and $\mathrm{CD}^{+} \mathrm{T}$ cells (112). Microvesicles can have a tolerogenic activity which can bring peripheral tolerance among autoreactive cells. Expressing PD-L1, galectin-1 and membrane-bound TGF- $\beta$ enable exosomes to inhibit proliferation of autoreactive cells and promote Treg cells generation more (113).

Microvesicles have also shown promising results when utilized in treatment of different diseases. It was shown that HGF released from MSCs-microvesicles was the agent to restore endothelial barrier function and decrease paracellular and transcellular permeability (114). Human embryonic MSCs-derived microvesicles presented promising therapeutic activities in anti-tumor defense; inhibiting leukemia cells proliferation, decreasing the BCL/Bax ratio and upregulating autophagy which can induce apop- tosis (115). The use of human MSCS-derived microvesicles on pneumonia-infected mice exhibited increased survival and decreased invasion of inflammatory cells, cytokines, and bacteria to the site of injury. It has also been shown that pretreatment of MSCs with TLR3 agonists could intensify the therapeutic effects of the microvesicles (116). A good therapeutic effect of MSCs-derived microvesicles through the transfer of mRNA has been revealed in an acute kidney injury (AKI) model. Microvesicles made epithelial cells more resistant to apoptosis and accelerated their functional recovery from glycerol-induced AKI in severe combined immunodeficiency (SCID) mice (117).

MSCs-derived apoptotic bodies: Another member of the extracellular vesicles are the apoptotic bodies. Apoptotic bodies' size is about 500 4000 nm. These vesicles can be derived from any dying cell. Excessive production of them, due to increased apoptosis, can lead to several neurological disorders like Parkinson's and Alzheimer's disease. Visa versa, reduced production of apoptotic bodies, as a result of decreased apoptosis, can lead to autoimmune disease development (118). They are enriched in histones, DNAs and noncoding RNAs and cell organelles are found inside of these extracellular vesicles. Apoptotic bodies express certain molecules like TSP, C3b and macrophage-related markers $(53,119,120)$.

These vesicles are absorbed by macrophages, dendritic cells, endothelial cells and fibroblasts and then they are degraded inside lysosomes of these cells. The cells use $\alpha \mathrm{v} \beta 3$ integrin to absorb apoptotic bodies. Phosphatidylserine on the surface of apoptotic bodies, as an "eat me" signal, play an important role in their recognition by phagocytes. Research studies on the therapeutic effects of apoptotic bodies are not as abundant as researches on exosomes and microvesicles. It has been shown that formation of apoptotic bodies has a significant role in osteogenic and adipogenic differentiation of bone marrow MSCs and they are involved in bone homeostasis and can be used to treat osteoporosis $(118,121)$.

\section{Epigenetic manipulation of MSCs}

Epigenetics is the set of inheritable alterations involving the expression of genes without mutations in the DNA sequence. For gene expression and other chromatin modifications, genes interact with transcriptional factors and nucleus modulators. These interactions are regulated by DNA methylation, histone modifications, microRNAs and chromatin remodeling which determine the fate of MSCs, their commitment and differentiation $(122,123)$. For instance, one method of cell therapy, is the use of micro- 
RNAs transfection, such as microRNA-378, under hypoxic-ischemic condition, which increase survival rate of MSCs (124). Also, Exosomal microRNAs (miRNAs) released by MSCs are hopeful therapeutic target for MI, Stroke, Alzheimer's disease (AD), Parkinson's disease (PD), and osteoarthritis (OA). This could be dependent on the role of miRNA in desired tissue biology, including tissue regeneration, cell differentiation, apoptosis, neovascularization, and remodeling (125).

\section{Genetic manipulation of MSCs}

Genetic manipulation is another way to improve MSC. Cumulating evidence have shown hopeful results of this method in the treatment of neurodegenerative, inflammatory and autoimmune diseases (126). Genetic modification of MSCs can drive different processes of cell differentiation like osteogenesis, adipogenesis, angiogenesis, and chondrogenesis (127). MSCs secrete several proangiogenic factors which promote formation of new vessels when used without any modifications (127). One of the most important proangiogenic factors is VEGF (128). It has been shown that VEGF-modified MSCs promoted angiogenesis and limb retention when injected into mouse ischemic hind limbs (129). Overexpression of adrenomedullin which produces a peptide promoting angiogenesis in MSCs improved capillary density and cardiac function in infarcted rat heart (130). Bone morphogenetic proteins (BMPs) and TGF- $\beta$ are two important factors that are used generally to promote osteogenesis and chondrogenesis (127).

There are various methods to deliver a therapeutic gene into MSCs. Transcription activator-like effector nuclease (TALEN), zinc finger nuclease (ZFN) and CRISPR/Cas system are some of the significant methods for genetic manipulation in MSCs. These enzymes start the break of double-stranded DNA; following this change, endogenous DNA repair starts and the desired sequence can be inserted into the genome (131). Viral and non-viral methods are used to deliver genes of interest into MSCs. Each method of transduction has its pros and cons. Viral methods yield high transduction efficiency and gene expression for a long period of time. On the other hand, non-viral methods show low transfection efficiency and transgene expression for a shorter period of time. However, they are less toxic and safer and also larger size of genes can be transferred into MSCs by using these methods (127).

Manipulation of MSCs can be a very good method for cell therapy if this modification bring improved survival of MSCs and the target tissues as well (127). Overexpress- ion of BCL-2 in rat BM-MSCs increased survival and enhanced heart tissue repair and organ regeneration after MI. Monkeys and porcine MSCs expressing hTERT gene showed longer lifespans and lessened apoptotic rate with increased proliferation (129). Using viral methods to overexpress Akt in MSCs causes increased survival of these cells. Secreted frizzled-related protein-2 (Sfrp2) is a factor released by Akt-MSCs, and it has a vital role in the survival of ischemic cardiac myocytes (132). Heat shock protein-20 (HSP-20) overexpression and hypoxic preconditioning increased survival of MSCs under ischemic situations. Also, use of the secreted agents as a conditioned medium of HSP-20-MSCs enhanced cardiomyocytes survival under oxidative situations (133).

Migration abilities of MSCs is another parameter that holds great significance in MSC-based therapy. Weak targeting abilities of MSCs is an important barrier which inhibits most of the therapeutic effects of these cells to be exerted on target cells. Genetic manipulation has been used to strengthen the migratory abilities of MSCs. CXCR4mRNA-transfected MSCs showed significantly enhanced migration toward SDF-1 gradient and improved infarcted myocardium (127). CCR1-expressing MSCs migrated to the site of injury especially in myocardium infarction (134). Since IL-10 and IL-18 from damaged myocardium cause MSCs death, overexpression of IL-18-binding protein in MSCs can lead to protection of them from cell death (135).

Mesenchymal stem cell-secreted factors can have anti-tumor effects on cancerous cells and inspiring results have been obtained from using MSCs soluble factors on glioma, hepatoma, melanoma, breast cancer and lung cancer $(136,137)$. IFN- $\alpha$-expressing MSCs increased apoptosis in a melanoma lung metastasis model and thus they induced decrease of cancerous cells proliferation. MSCs expressing CX3CL1, a T cell attractant chemokine, show inhibition of cancerous cells metastasis to lung tissue after injection of cancerous cells. TRAIL-expressing MSCs induced apoptosis in various cancer cell lines (129).

An example of application of ex vivo genetic manipulation is the use of this method in acute lung injury (ALI). Angiotensin II (Ang II) is upregulated in the injured part of lung tissue. Systemic injection of MSC-AT2R (angiotensin II receptor) into ALI mice reduced pulmonary vascular permeability and amended the lung histopathology and had further anti-inflammatory effects (138).

There are several trophic factors released by MSCs that can have good impacts on some neurodegenerative diseases. Glial cell-derived neurotrophic factor (GDNF), brainderived neurotrophic factor (BDNF), and nerve growth 
factor (NGF) are therapeutic factors that can improve Parkinson's disease, Huntington's disease and Alzheimer's disease. Genetically modifying MSCs to overexpress these proteins can be useful for better results in therapies of neurodegenerative diseases (Fig. 2) (131).

\section{Applications of MSCs in the Treatment of Neurodegenerative Diseases}

\section{Alzheimer's disease}

Alzheimer's disease (AD) is the most prevalent neurodegenerative disease which affects approximately 47 million people worldwide. Aging is presumed to be the most important risk factor for $\mathrm{AD}$ development. Continuous synaptic damage and neuronal loss, resulting in slow cognitive deterioration and dementia, are the characteristics of the disease. The main microscopic and pathological marks of $\mathrm{AD}$ are the amyloid beta and Tau protein agglomerated within the brain (139-141). It is not known for certain whether these plaques and tangles are protective or causative. Decreased levels of acetylcholine, acetylcholinesterase (AChE) and acetyltransferase in the hippocampus and neocortex and reduced levels of neurons in the basal forebrain cholinergic nuclei (BFChN) are the reasons for cholinergic formation hypothesis of the disease (131). Approved drugs for Alzheimer's disease only im-

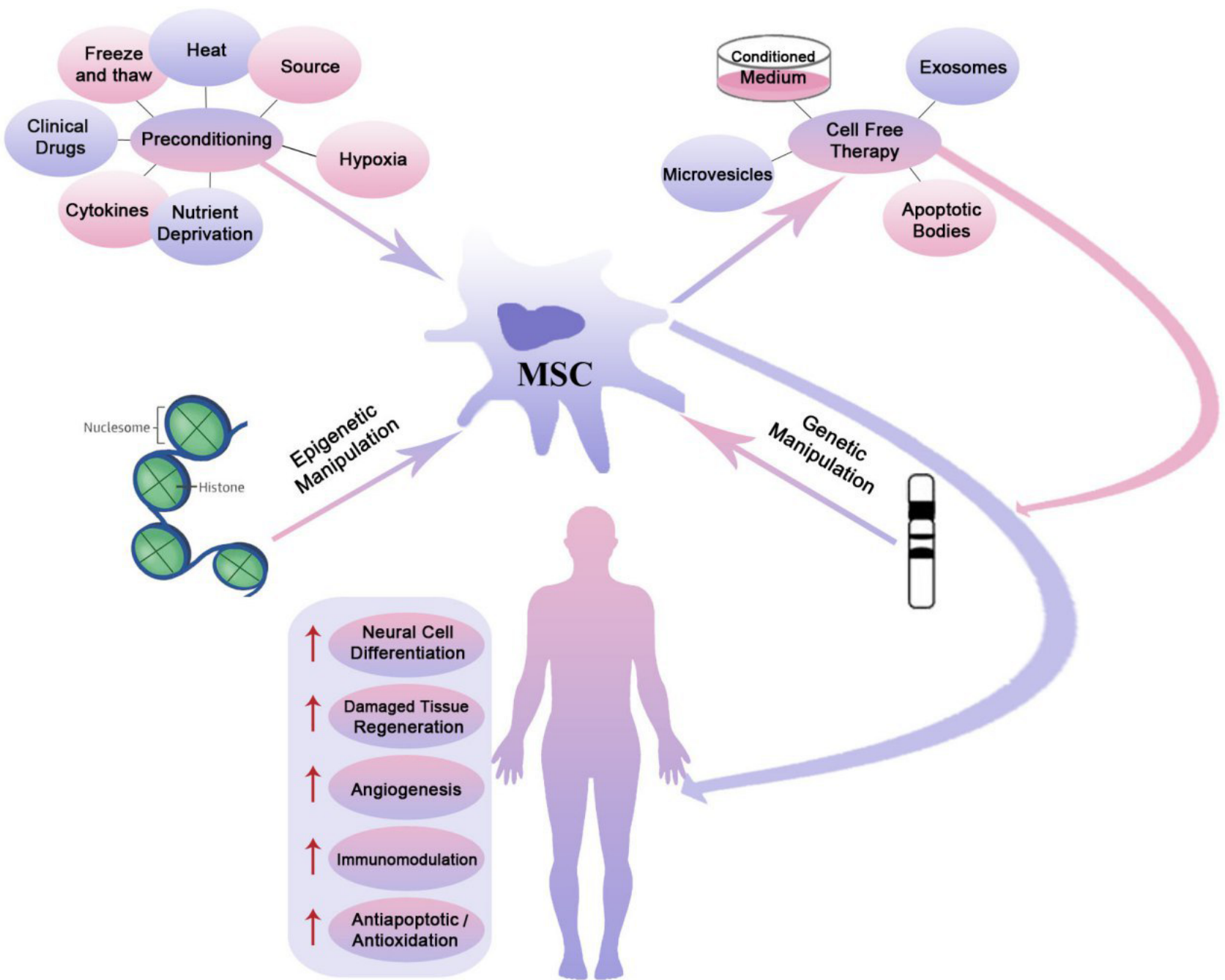

Fig. 2. Modifications of mesenchymal stem cells (MSCs). Preconditioning, genetic and epigenetic manipulation of MSCs and also cell free therapy are key strategies to get better survival, proliferation and function of MSCs. Manipulation of MSCs increase neural cell differentiation, regeneration of damaged tissue, angiogenesis, immunomodulation, and also improve antiapoptotic/antioxidation effects of MSCs which are used in treatment of neurodegenerative diseases. 
pede the progression of the disease and they have tranquilizing effects in almost all of the cases $(131,142)$. Although preclinical studies of stem cell-based therapies in $\mathrm{AD}$ exhibited variable effects, they are mostly associated with decrease in the $\mathrm{A} \beta$ load and increase in the $\mathrm{A} \beta$-degrading enzymes. The results gained from stem cell therapy in $\mathrm{AD}$ is typically dependent on the types and sources of MSCs. Mesenchymal stem cells exert their therapeutical effects through four main mechanisms which are: 1) restoring the degenerated neurons; 2) neuroprotection through secreted factors; 3) exerting immunomodulatory effects on the cells responsible for the disease development; and 4) proliferation of the endogenous cells (143).

By enhancing the PI3k/Akt pathway, glycogen synthase kinase 3 beta enzyme (GSK3 $\beta$ ) plays an important role in AD pathogenesis. Transcriptomic analysis of MSCs especially gingiva-derived MSCs pretreated with cannabidiol (CBD) showed inhibition of GSK3 $\beta$ via binding to TRPV1 receptor. CBD also decreased the expression of genes coding for the kinases and secretases involved in tau protein phosphorylation and $\mathrm{A} \beta$ formation, respectively (144). On the other hand, in Alzheimer's disease, the balance between inflammatory and immune-regulatory responses is dysregulated and a chronic inflammation occurs. It is well indicated that systematic administration of hypoxia-preconditioned MSCs to APP/PS1 mice (AD disease mouse model) induces the secretion of miR-21-enrtiched exosomes, which are important in the control of this balance. This upregulation of miR-21 enhanced memory abilities of mice and $\mathrm{A} \beta$ plaque depositions were lessened (145).

Moreover, soluble factors derived from MSCs have shown great therapeutical effects in AD. Activin A, released from MSCs in the coculture of human MSCs with subventricular zone-derived neural cells of 5XFAD mice, caused neural cells to develop and growth (146). Growth differentiation factor-15 (GDF-15) released by neural stem cells (NSCs) in the media of human UCB-MSCs (hUCBMSCs) enhanced proliferation of NSCs in hUCB-MSCsNSCs coculture (147). Transplantation of MSCs to the brains of $\mathrm{AD}$ mice led to the release of CCL5 from BMMSCs. In fact, the amyloid beta-enriched regions stimulate the secretion of CCL5, the attracting chemokine released by microglia cells to help the phagocytosis and removal of $\mathrm{A} \beta$ plaques. Memory function was enhanced by IL-4 and neprilysin (NEP) production of alternative microglia. NEP is a zinc-dependent metalloprotease that degrades A $\beta$ plaques (148). Administration of microglial cells coupled with recombinant ICAM-1 into the mice brain causes the expression of NEP in dose and time-de- pendent manner as well (149). Proteasome complex activity is downregulated in Alzheimer's disease and it results in the accumulation of ubiquitin-conjugated proteins. Lee et al. (150) showed that agouti-related peptide (AgRP) released from human MSCs enhance the proteasome complex activity and administration of human MSCs or the AgRP itself to the hippocampus of $5 \mathrm{XFAD}$ mice can decrease the accumulation of unwanted proteins in the brain. Thrombospondin (TSP-1) is another secreted molecule from hUCB-MSCs to relieve synaptic dysfunction, caused by $\mathrm{A} \beta$ peptides (151).

Genetic manipulation of MSCs has yielded promising results in enhancing MSCs effects. MSCs increase neurogenesis and differentiation of neural progenitor cells into mature neurons by enhancing the Wnt pathway (152). The exosomes and microvesicles released from modified MSCs are enriched in factors of interest to enhance the therapeutic effects. Overexpression of $\mathrm{A} \beta$ degrading enzymes or downregulation of secretase enzymes related to $\mathrm{A} \beta$ formation with transfecting different RNAs can be useful in ameliorating disease symptoms (153). Brn-4 protein in MSCs can inhibit the accumulation of $\mathrm{A} \beta$ in the brain but miR-937 presence impedes the translation of Brn-4 mRNA to protein. Administration of (Antisense)-miR-937MSCs helped in A $\beta$ deposition reduction and clearance in the brain $(154,155)$. Overexpression of BDNF in MSCs extended survival and increased synaptic markers in neurons of 5XFAD mouse, and APP/PS1 transgenic mouse model $(156,157)$.

\section{Parkinson's disease}

After AD, Parkinson's disease (PD) is identified as the second most common neurodegenerative disease, which causes severe movement disorder, tremor, rigidity, and postural instability $(158,159)$. Presence of abnormal alpha-synuclein protein aggregates inside the brain is the most important neuropathological characteristic of the disease (160). Gait difficulties in PD are because of gradual degeneration of neurons in the substantia nigra. The main responsibility of these neurons is to produce dopamine to keep balance in motor activities (161). Most of the treatments for Parkinson's disease are about the restoration of dopamine inside the brain but too many side effects of these treatments have prompted researchers to look for alternative therapeutical agents. One promising target is the use of regenerative medicine especially stem cells in the amelioration and treatment of the disease (158, 161).

Mesenchymal stem cells play an important role in blocking of $\alpha$-synuclein transmission. MSCs do this through 
interaction with N-methyl-D-aspartate receptors and inhibition of $\alpha$-synuclein endocytosis. Surveys have shown that secreted factor "galectin-1" has an important involvement in the control of transmission of $\alpha$-synuclein (162, 163).

As discussed previously, pretreatment of MSCs with different conditions and agents can enhance the therapeutic actions of MSCs. This method has shown great results in the therapy of PD as well. Hypoxic preconditioning of MSCs (3\% O2 treatment) in the process of neural differentiation has led to an increase in HIF-1 $\alpha$ expression, phosphorylation of P38 MAPK and Erk. These changes in the genetic profile of MSCs resulted in enhanced neurosphere generation, dopaminergic neuronal differentiation alongside increased differentiation of neuronal cells. Neurons generated by hypoxic preconditioning exhibit elongated survival and can be more therapeutic than ordinary neurons (164). PC12 cells (a cell model of PD) affected by the supernatant of curcumin pretreated hUC-MSCs showed enhanced proliferation and elevated expression of microtubule associated protein-2 (MAP-2) and tyrosin hydroxylase, a rate-limiting enzyme in dopamine synthesis. These effects were not seen to this extent when using the supernatants of hUC-MSCs alone. This shows that preconditioning of MSCs by curcumin can enhance their therapeutic applications in PD (165).

Using the secreted agents from MSCs as cell-free therapy can have beneficial effects on Parkinson's disease as well. ROS generation is one of the pathological hallmarks of PD. Neuroblastoma SH-SY5Y cells were pretreated with the conditioned medium extracted from rat adipose tissue-derived MSCs (AT-MSCs) to check MSCs conditioned media's effect on pro-oxidizing agents. Neuroblastoma cells cocultured with conditioned media showed more decreased mortality and ROS generation when treated with H2O2 or 6-OHDA (6-hydroxydopamine), a dopaminergic selective toxin; than Neuroblastoma cells not preconditioned with conditioned media (166). MSCs conditioned medium is a good therapeutic candidate as neural stem cells, pretreated with conditioned medium (CM-NSCs) showed increased survival and enhanced migratory activity; but NSCs alone lacked these extra characteristics (167).

Genetically engineered MSCs exhibit increased functional and therapeutical activities. Conserved dopamine neurotrophic factor (CDNF)-expressing BM-MSCs can reduce 6-OHDA induced neurotoxicity on dopaminergic neurons and enhance behavioral recovery of these cells (168). Another gene responsible for CNS tissues protection is neurotrophin-3 (nt-3gene) which enhances neuronal-like differentiation. Overexpression of this gene in MSCs promotes the expression of tyrosine hydroxylase (TH), an indicator of the intracellular signaling in dopaminergic neuron differentiation (169).

Adenoviral and lentiviral delivery of specific genes into MSCs could have good results on PD therapy. Hepatocyte growth factor expressing MSCs enhance recreation of damaged neurons. They also express LMX1a, an essential participant in dopaminergic differentiation, which increase tyrosine hydroxylase and dopaminergic genes expression $(170,171)$.

\section{Huntington's disease}

Huntington's disease (HD) is the most prevalent monogenic neurodegenerative disease which is inherited in an autosomal dominant pattern and occurs when polyglutamine (CAG) repeats exist in the first exon of Huntingtin gene, located on the short arm of the fourth chromosome. The mutation inside this gene leads to bad protein production which ultimately causes the symptoms of the disease such as choreic movement and troubles in cognitive and emotional feelings. HD leads to death in most of the patients $(131,172,173)$. Lack of a suitable conventional therapy is a characteristic shared between most of the neurodegenerative diseases such as HD. Mesenchymal stem cells have been tested on HD because of high differentiation capacity to neuronal cells and ameliorating effects of them (174).

MSCs secrete a wide range of neurotrophic factors, show anti-inflammatory effects and are less vulnerable to getting rejected. Therefore, they have shown enough capability to slow the beginning of neurodegenerative deficiencies and behavioral incompetence. Neuropathological symptoms of $\mathrm{HD}$ in rodent models relieved after intrastriatal transplantation of MSCs $(175,176)$. The decrease in neurotrophic factors (NTFs) can have an important involvement in HD development. Specific procedures have been developed to induce BM-MSCs to secret NTFs. Transplantation of these NTFs-secreting MSCs to the brains of rats after quinolinic acid (QA) injection, as a model for HD, decreased striatal mass changes and had beneficial therapeutic effects (177). Human BM-MSCs can integrate with the host cells to increase the level of some secreted factors like von willebrand factor (VWF), SDF-1 and its receptor CXCR4. Transplanted MSCs can decrease the expression of apoptotic factors, including Bax and Caspase-3, and increase P-Erk1/2 expression (178).

Preconditioning of MSCs with lithium and valproic acid, commonly used as mood stabilizers, can improve the therapeutic efficacy of these cells. Preconditioned MSCs 
lessened $\mathrm{HD}$ aggregates in $\mathrm{HD}$ mice and hampered striatal neuronal loss. These MSCs exhibited intragenic effects such as an enhanced expression of antioxidants, migration-related genes, and anti-apoptosis molecules. This level of gene expression profile was not seen when using unpreconditioned cells (75).

Because genetic profile has an important role in the formation of HD, genetic manipulation of MSCs can be really useful in HD therapy. MSCs can be used to transfer specific interfering RNAs (RNAi) which can target mutant and defective huntingtin in neuronal cells (179). Genetically manipulating MSCs to overexpress neural growth factors (ex: BDNF and GDNF) and transplanting these cells through intrathecal or intracerebral way can exert neuroprotective effects. They can reduce both free radicals levels and apoptosis in neuronal cells. BDNF can create a situation inside the striatum that slows neurodegeneration in the YAC128 HD mouse model (Table 1) $(180,181)$.

\section{Conclusions}

Neurodegenerative diseases impose a huge burden on every aspect of life. The fact that there is no proper treatment for most of these diseases, has become a great incentive for researchers to focus on regenerative medicine.

Table 1. The list of therapeutic applications of MSCs in Alzheimer disease (AD), Parkinson's disease (PD), and Huntington's disease (HD)

\begin{tabular}{|c|c|c|}
\hline Disease & Applications of MSCs & References \\
\hline \multirow[t]{8}{*}{$\mathrm{AD}$} & - Modulation of the expression of AD-related genes in gingiva-derived MSCs by CBD. & (144) \\
\hline & $\begin{array}{l}\text { - Amelioration of cognitive decline by rescuing synaptic dysfunction and regulating inflammatory responses in } \\
\text { APP/PS1 mice through miR-21 enriched exosomes derived from hypoxia-preconditioned MSCs. }\end{array}$ & (145) \\
\hline & $\begin{array}{l}\text { - Neural development and neurite outgrowth induced by Activin A, secreted by human MSCs in an in vitro model } \\
\text { of AD. }\end{array}$ & (146) \\
\hline & $\begin{array}{l}\text { - Amelioration of AD mice through soluble CCL5 produced from bone marrow-derived MSCs by recruiting bone } \\
\text { marrow-induced microglia immune responses, including phagocytosis, and IL-4 and NEP production. }\end{array}$ & (148) \\
\hline & - AgRP released from human MSCs upregulates proteasome activity in 5XFAD mice, an AD model. & (150) \\
\hline & $\begin{array}{l}\text { - The rescue of neurons from synaptic dysfunction through thrombospondin-1 secreted by human umbilical cord } \\
\text { blood-derived MSCS in AD model. }\end{array}$ & (151) \\
\hline & $\begin{array}{l}\text { - Administration of antisense-miR-937-MSCs to help to decrease and clearance of } \mathrm{A} \beta \text { deposition in the brain } \\
\text { through inhibiting the translation of Brn-4 mRNA. }\end{array}$ & $(154,155)$ \\
\hline & $\begin{array}{l}\text { - Extended survival and increased synaptic markers in neurons of 5XFAD mouse, and APP/PS1 transgenic mouse } \\
\text { model by overexpression of BDNF in MSCs. }\end{array}$ & $(156,157)$ \\
\hline \multirow[t]{7}{*}{ PD } & $\begin{array}{l}\text { - Blocking of } \alpha \text {-synuclein transmission by MSCs through inhibition of } \alpha \text {-synuclein endocytosis and galectin-1 } \\
\text { secretion in PD model. }\end{array}$ & $(162,163)$ \\
\hline & $\begin{array}{l}\text { - Hypoxia preconditioning of MSCs for promoting dopaminergic differentiation of MSCs and elongated survival } \\
\text { of neurons in a rat model of PD. }\end{array}$ & (164) \\
\hline & $\begin{array}{l}\text { - Preconditioning of MSCs by curcumin on 1-Methyl-4-phenylpyridine-Induced PD Cell Model lead to enhanced } \\
\text { proliferation and elevated expression of MAP-2 and tyrosin hydroxylase. }\end{array}$ & (165) \\
\hline & - MSC-Secreted Factors and Neural Stem Cell coculture and Transplantation increase Recovery of PD Rat model. & $(167)$ \\
\hline & $\begin{array}{l}\text { - Genetically engineered CDNF-expressing MSCs reduced 6-OHDA induced neurotoxicity on dopaminergic } \\
\text { neurons. }\end{array}$ & (168) \\
\hline & $\begin{array}{l}\text { - Brain tissue engineering through combination of NT3-overexpressing MSCs and PLGA microcarriers as a } \\
\text { promising tool for treatment of PD. }\end{array}$ & (169) \\
\hline & - Lentiviral delivery of LMX1a and HGF into human bone marrow MSCs for PD therapy. & $(170,171)$ \\
\hline \multirow[t]{3}{*}{ HD } & $\begin{array}{l}\text { - A potential therapy for HD rat model through transplantation of NTF-secreting MSCs to the brains of Rats after } \\
\text { QA injection. }\end{array}$ & $(177)$ \\
\hline & $\begin{array}{l}\text { - Transplanted human BM-MSCs prolong survival and ameliorate motor deficit through decrease of Bax and } \\
\text { caspase } 3 \text { and increase of Erk } 1 / 2 \text { in HD mouse models. }\end{array}$ & (178) \\
\hline & $\begin{array}{l}\text { - Lessening of HD aggregates in HD mice by preconditioning MSCs with lithium and VPA exhibiting intragenic } \\
\text { effects like an enhanced expression of antioxidants, migration-related genes, and anti-apoptosis molecules. } \\
\text { - Genetically manipulating of MSCs to transfer specific RNAi targeting mutant and defective huntingtin in neuronal } \\
\text { cells or overexpressing BDNF and GDNF exerting neuroprotective effects. }\end{array}$ & $(179 \sim 181)$ \\
\hline
\end{tabular}

AD: Alzheimer's disease, PD: Parkinson's disease; HD: Huntington's disease, MSCs: Mesenchymal stem cells, CBD: Cannabidiol, AgRP: Agouti-related peptide, BDNF: Brain derived neurotrophic factor, CDNF: Cerebral dopamine neurotrophic factor, 6-OHDA: 6-hydroxydopamine, NT3: Neurotrophin-3, HGF: Hepatocyte growth factor, NTF: Neurotrophic factor, QA: Quinolinic acid, VPA: Valproic acid. 
In this field, the use of mesenchymal stem cells has yielded good results. MSCs are multipotent cells that have self-renewal, neuroprotective and regenerative abilities and can differentiate into a number of cell types which makes them perfect candidates for regenerative medicine. MSCs have a lot of therapeutic applications as they can have modulatory effects on almost all of immune cells. Therapeutic applications of MSCs can be strengthened by manipulating different aspects of them. MSCs can be pretreated with different subjects, manipulated genetically or cultured to take their secretome.

\section{Acknowledgments}

This research has been supported by Baqiyatallah University of Medical Sciences and also Tehran University of Medical Sciences.

\section{Potential Conflict of Interest}

The authors have no conflicting financial interest.

\section{References}

1. Wei X, Yang X, Han ZP, Qu FF, Shao L, Shi YF. Mesenchymal stem cells: a new trend for cell therapy. Acta Pharmacol Sin 2013;34:747-754

2. Samsonraj RM, Raghunath M, Nurcombe V, Hui JH, van Wijnen AJ, Cool SM. Concise review: multifaceted characterization of human mesenchymal stem cells for use in regenerative medicine. Stem Cells Transl Med 2017;6:21732185

3. Ryan JM, Barry FP, Murphy JM, Mahon BP. Mesenchymal stem cells avoid allogeneic rejection. J Inflamm (Lond) 2005;2:8

4. Klyushnenkova E, Mosca JD, Zernetkina V, Majumdar MK, Beggs KJ, Simonetti DW, Deans RJ, McIntosh KR. $\mathrm{T}$ cell responses to allogeneic human mesenchymal stem cells: immunogenicity, tolerance, and suppression. J Biomed Sci 2005;12:47-57

5. Eto S, Goto M, Soga M, Kaneko Y, Uehara Y, Mizuta H, Era T. Mesenchymal stem cells derived from human iPS cells via mesoderm and neuroepithelium have different features and therapeutic potentials. PLoS One 2018;13: e0200790

6. Ryu CM, Yu HY, Lee HY, Shin JH, Lee S, Ju H, Paulson B, Lee S, Kim S, Lim J, Heo J, Hong KS, Chung HM, Kim JK, Shin DM, Choo MS. Longitudinal intravital imaging of transplanted mesenchymal stem cells elucidates their functional integration and therapeutic potency in an animal model of interstitial cystitis/bladder pain syndrome. Theranostics 2018;8:5610-5624

7. Hass R, Kasper C, Böhm S, Jacobs R. Different populations and sources of human mesenchymal stem cells (MSC): a comparison of adult and neonatal tissue-derived
MSC. Cell Commun Signal 2011;9:12

8. Pittenger MF, Mackay AM, Beck SC, Jaiswal RK, Douglas R, Mosca JD, Moorman MA, Simonetti DW, Craig S, Marshak DR. Multilineage potential of adult human mesenchymal stem cells. Science 1999;284:143-147

9. Okolicsanyi RK, Camilleri ET, Oikari LE, Yu C, Cool SM, van Wijnen AJ, Griffiths LR, Haupt LM. Human mesenchymal stem cells retain multilineage differentiation capacity including neural marker expression after extended in vitro expansion. PLoS One 2015;10:e137255

10. Dominici M, Le Blanc K, Mueller I, Slaper-Cortenbach I, Marini F, Krause D, Deans R, Keating A, Prockop Dj, Horwitz E. Minimal criteria for defining multipotent mesenchymal stromal cells. The International Society for Cellular Therapy position statement. Cytotherapy 2006;8: 315-317

11. Bae S, Shim SH, Park CW, Son HK, Lee HJ, Son JY, Jeon $\mathrm{C}$, Kim H. Combined omics analysis identifies transmembrane 4 L6 family member 1 as a surface protein marker specific to human mesenchymal stem cells. Stem Cells Dev 2011;20:197-203

12. Fouillard L, Chapel A, Bories D, Bouchet S, Costa JM, Rouard H, Hervé P, Gourmelon P, Thierry D, Lopez M, Gorin NC. Infusion of allogeneic-related HLA mismatched mesenchymal stem cells for the treatment of incomplete engraftment following autologous haematopoietic stem cell transplantation. Leukemia 2007;21:568-570

13. Parekkadan B, Milwid JM. Mesenchymal stem cells as therapeutics. Annu Rev Biomed Eng 2010;12:87-117

14. Kim HJ, Park JS. Usage of human mesenchymal stem cells in cell-based therapy: advantages and disadvantages. Dev Reprod 2017;21:1-10

15. Chen SL, Fang WW, Ye F, Liu YH, Qian J, Shan SJ, Zhang JJ, Chunhua RZ, Liao LM, Lin S, Sun JP. Effect on left ventricular function of intracoronary transplantation of autologous bone marrow mesenchymal stem cell in patients with acute myocardial infarction. Am J Cardiol 2004;94:92-95

16. Lee PH, Kim JW, Bang OY, Ahn YH, Joo IS, Huh K. Autologous mesenchymal stem cell therapy delays the progression of neurological deficits in patients with multiple system atrophy. Clin Pharmacol Ther 2008;83:723-730

17. Murray CJ, Vos T, Lozano R, Naghavi M, Flaxman AD, Michaud C, Ezzati M, Shibuya K, Salomon JA, Abdalla S, Aboyans V, Abraham J, Ackerman I, Aggarwal R, Ahn SY, Ali MK, Alvarado M, Anderson HR, Anderson LM, Andrews KG, Atkinson C, Baddour LM, Bahalim AN, Barker-Collo S, Barrero LH, Bartels DH, Basáñez MG, Baxter A, Bell ML, Benjamin EJ, Bennett D, Bernabé E, Bhalla K, Bhandari B, Bikbov B, Bin Abdulhak A, Birbeck G, Black JA, Blencowe H, Blore JD, Blyth F, Bolliger I, Bonaventure A, Boufous S, Bourne R, Boussinesq $M$, Braithwaite T, Brayne C, Bridgett L, Brooker S, Brooks P, Brugha TS, Bryan-Hancock C, Bucello C, Buchbinder R, Buckle G, Budke CM, Burch M, Burney P, Burstein R, Calabria B, Campbell B, Canter CE, Carabin H, Carapetis 
J, Carmona L, Cella C, Charlson F, Chen H, Cheng AT, Chou D, Chugh SS, Coffeng LE, Colan SD, Colquhoun S, Colson KE, Condon J, Connor MD, Cooper LT, Corriere M, Cortinovis M, de Vaccaro KC, Couser W, Cowie BC, Criqui MH, Cross M, Dabhadkar KC, Dahiya M, Dahodwala N, Damsere-Derry J, Danaei G, Davis A, De Leo D, Degenhardt L, Dellavalle R, Delossantos A, Denenberg J, Derrett S, Des Jarlais DC, Dharmaratne SD, Dherani M, Diaz-Torne C, Dolk H, Dorsey ER, Driscoll T, Duber H, Ebel B, Edmond K, Elbaz A, Ali SE, Erskine H, Erwin PJ, Espindola P, Ewoigbokhan SE, Farzadfar F, Feigin V, Felson DT, Ferrari A, Ferri CP, Fèvre EM, Finucane MM, Flaxman S, Flood L, Foreman K, Forouzanfar $\mathrm{MH}$, Fowkes FG, Fransen M, Freeman MK, Gabbe BJ, Gabriel SE, Gakidou E, Ganatra HA, Garcia B, Gaspari F, Gillum RF, Gmel G, Gonzalez-Medina D, Gosselin R, Grainger R, Grant B, Groeger J, Guillemin F, Gunnell D, Gupta R, Haagsma J, Hagan H, Halasa YA, Hall W, Haring D, Haro JM, Harrison JE, Havmoeller R, Hay RJ, Higashi H, Hill C, Hoen B, Hoffman H, Hotez PJ, Hoy D, Huang JJ, Ibeanusi SE, Jacobsen $\mathrm{KH}$, James SL, Jarvis D, Jasrasaria R, Jayaraman S, Johns N, Jonas JB, Karthikeyan G, Kassebaum N, Kawakami N, Keren A, Khoo JP, King CH, Knowlton LM, Kobusingye O, Koranteng A, Krishnamurthi R, Laden F, Lalloo R, Laslett LL, Lathlean T, Leasher JL, Lee YY, Leigh J, Levinson D, Lim SS, Limb E, Lin JK, Lipnick M, Lipshultz SE, Liu W, Loane M, Ohno SL, Lyons R, Mabweijano J, MacIntyre MF, Malekzadeh R, Mallinger L, Manivannan S, Marcenes W, March L, Margolis DJ, Marks GB, Marks R, Matsumori A, Matzopoulos R, Mayosi BM, McAnulty JH, McDermott MM, McGill N, McGrath J, Medina-Mora ME, Meltzer M, Mensah GA, Merriman TR, Meyer AC, Miglioli V, Miller M, Miller TR, Mitchell PB, Mock C, Mocumbi AO, Moffitt TE, Mokdad AA, Monasta L, Montico M, Moradi-Lakeh M, Moran A, Morawska L, Mori R, Murdoch ME, Mwaniki MK, Naidoo K, Nair MN, Naldi L, Narayan KM, Nelson PK, Nelson RG, Nevitt MC, Newton CR, Nolte S, Norman P, Norman R, O'Donnell M, O'Hanlon S, Olives C, Omer SB, Ortblad K, Osborne R, Ozgediz D, Page A, Pahari B, Pandian JD, Rivero AP, Patten SB, Pearce N, Padilla RP, Perez-Ruiz F, Perico N, Pesudovs K, Phillips D, Phillips MR, Pierce K, Pion S, Polanczyk GV, Polinder S, Pope CA 3rd, Popova S, Porrini E, Pourmalek F, Prince M, Pullan RL, Ramaiah KD, Ranganathan D, Razavi H, Regan M, Rehm JT, Rein DB, Remuzzi G, Richardson K, Rivara FP, Roberts T, Robinson C, De Leòn FR, Ronfani L, Room R, Rosenfeld LC, Rushton L, Sacco RL, Saha S, Sampson U, Sanchez-Riera L, Sanman E, Schwebel DC, Scott JG, Segui-Gomez M, Shahraz S, Shepard DS, Shin H, Shivakoti R, Singh D, Singh GM, Singh JA, Singleton J, Sleet DA, Sliwa K, Smith E, Smith JL, Stapelberg NJ, Steer A, Steiner T, Stolk WA, Stovner LJ, Sudfeld C, Syed S, Tamburlini G, Tavakkoli M, Taylor HR, Taylor JA, Taylor WJ, Thomas B, Thomson WM, Thurston GD, Tleyjeh IM, Tonelli M, Towbin JA, Truelsen T, Tsilimba- ris $\mathrm{MK}$, Ubeda $\mathrm{C}$, Undurraga $\mathrm{EA}$, van der Werf $\mathrm{MJ}$, van Os J, Vavilala MS, Venketasubramanian N, Wang $M$, Wang W, Watt K, Weatherall DJ, Weinstock MA, Weintraub R, Weisskopf MG, Weissman MM, White RA, Whiteford $\mathrm{H}$, Wiebe $\mathrm{N}$, Wiersma ST, Wilkinson JD, Williams HC, Williams SR, Witt E, Wolfe F, Woolf AD, Wulf S, Yeh PH, Zaidi AK, Zheng ZJ, Zonies D, Lopez AD, AlMazroa MA, Memish ZA. Disability-adjusted life years (DALYs) for 291 diseases and injuries in 21 regions, 1990-2010: a systematic analysis for the Global Burden of Disease Study 2010. Lancet 2012;380:2197-2223

18. Tabrizi S. Neurodegenerative diseases neurobiology pathogenesis and therapeutics. J Neurol Neurosurg Psychiatr 2006;77:284

19. Höglund K, Salter H. Molecular biomarkers of neurodegeneration. Expert Rev Mol Diagn 2013;13:845-861

20. Metcalfe SM, Bickerton S, Fahmy T. Neurodegenerative disease: a perspective on cell-based therapy in the new era of cell-free nano-therapy. Curr Pharm Des 2017;23:776-783

21. Robbins MR. Neurologic diseases in special care patients. Dent Clin North Am 2016;60:707-735

22. Brettschneider J, Del Tredici K, Lee VM, Trojanowski JQ. Spreading of pathology in neurodegenerative diseases: a focus on human studies. Nat Rev Neurosci 2015;16:109-120

23. Dugger BN, Dickson DW. Pathology of neurodegenerative diseases. Cold Spring Harb Perspect Biol 2017;9:a028035

24. Chen WW, Zhang X, Huang WJ. Role of neuroinflammation in neurodegenerative diseases (review). Mol Med Rep 2016;13:3391-3396

25. Gharibi T, Ahmadi M, Seyfizadeh N, Jadidi-Niaragh F, Yousefi M. Immunomodulatory characteristics of mesenchymal stem cells and their role in the treatment of multiple sclerosis. Cell Immunol 2015;293:113-121

26. Kadle RL, Abdou SA, Villarreal-Ponce AP, Soares MA, Sultan DL, David JA, Massie J, Rifkin WJ, Rabbani P, Ceradini DJ. Microenvironmental cues enhance mesenchymal stem cell-mediated immunomodulation and regulatory T-cell expansion. PLoS One 2018;13:e0193178

27. Andreeva E, Bobyleva P, Gornostaeva A, Buravkova L. Interaction of multipotent mesenchymal stromal and immune cells: bidirectional effects. Cytotherapy 2017;19: 1152-1166

28. English K, Mahon BP. Allogeneic mesenchymal stem cells: agents of immune modulation. J Cell Biochem 2011;112: 1963-1968

29. Di Nicola M, Carlo-Stella C, Magni M, Milanesi M, Longoni PD, Matteucci P, Grisanti S, Gianni AM. Human bone marrow stromal cells suppress T-lymphocyte proliferation induced by cellular or nonspecific mitogenic stimuli. Blood 2002;99:3838-3843

30. Najar M, Fayyad-Kazan M, Merimi M, Burny A, Bron D, Fayyad-Kazan H, Meuleman N, Lagneaux L. Mesenchymal stromal cells and natural killer cells: a complex story of love and hate. Curr Stem Cell Res Ther 2019;14:14-21

31. Poggi A, Varesano S, Zocchi MR. How to hit mesenchymal stromal cells and make the tumor microenvironment im- 
munostimulant rather than immunosuppressive. Front Immunol 2018;9:262

32. Berg J, Roch M, Altschüler J, Winter C, Schwerk A, Kurtz A, Steiner B. Human adipose-derived mesenchymal stem cells improve motor functions and are neuroprotective in the 6-hydroxydopamine-rat model for Parkinson's disease when cultured in monolayer cultures but suppress hippocampal neurogenesis and hippocampal memory function when cultured in spheroids. Stem Cell Rev 2015;11:133-149

33. Papazian I, Kyrargyri V, Evangelidou M, Voulgari-Kokota A, Probert L. Mesenchymal stem cell protection of neurons against glutamate excitotoxicity involves reduction of NMDA-triggered calcium responses and surface GluR1, and is partly mediated by TNF. Int J Mol Sci 2018;19:E651

34. Jang S, Kang YH, Ullah I, Shivakumar SB, Rho GJ, Cho YC, Sung IY, Park BW. Cholinergic nerve differentiation of mesenchymal stem cells derived from long-term cryopreserved human dental pulp in vitro and analysis of their motor nerve regeneration potential in vivo. Int $\mathrm{J}$ Mol Sci 2018;19:E2434

35. Jeon HJ, Park J, Shin JH, Chang MS. Insulin-like growth factor binding protein-6 released from human mesenchymal stem cells confers neuronal protection through IGF1R-mediated signaling. Int J Mol Med 2017;40:1860-1868

36. Ding H, Zhang H, Ding H, Li D, Yi X, Ma X, Li R, Huang M, Ju X. Transplantation of placenta-derived mesenchymal stem cells reduces hypoxic-ischemic brain damage in rats by ameliorating the inflammatory response. Cell Mol Immunol 2017;14:693-701

37. Oh SH, Choi C, Noh JE, Lee N, Jeong YW, Jeon I, Shin JM, Kim JH, Kim HJ, Lee JM, Kim HS, Kim OJ, Song J. Interleukin-1 receptor antagonist-mediated neuroprotection by umbilical cord-derived mesenchymal stromal cells following transplantation into a rodent stroke model. Exp Mol Med 2018;50:22

38. Laroni A, de Rosbo NK, Uccelli A. Mesenchymal stem cells for the treatment of neurological diseases: immunoregulation beyond neuroprotection. Immunol Lett 2015;168: 183-190

39. Creusot RJ, Postigo-Fernandez J, Teteloshvili N. Altered function of antigen-presenting cells in type 1 diabetes: a challenge for antigen-specific immunotherapy? Diabetes 2018;67:1481-1494

40. Abumaree MH, Abomaray FM, Alshabibi MA, AlAskar AS, Kalionis B. Immunomodulatory properties of human placental mesenchymal stem/stromal cells. Placenta 2017;59: 87-95

41. Spaggiari GM, Capobianco A, Becchetti S, Mingari MC, Moretta L. Mesenchymal stem cell-natural killer cell interactions: evidence that activated NK cells are capable of killing MSCs, whereas MSCs can inhibit IL-2-induced NK-cell proliferation. Blood 2006;107:1484-1490

42. Wu J, Ji C, Cao F, Lui H, Xia B, Wang L. Bone marrow mesenchymal stem cells inhibit dendritic cells differentiation and maturation by microRNA-23b. Biosci Rep 2017;37:BSR20160436
43. Zhang Y, Ge XH, Guo XJ, Guan SB, Li XM, Gu W, Xu WG. Bone marrow mesenchymal stem cells inhibit the function of dendritic cells by secreting galectin-1. Biomed Res Int 2017;2017:3248605

44. Arsenijevic A, Harrell CR, Fellabaum C, Volarevic V. Mesenchymal stem cells as new therapeutic agents for the treatment of primary biliary cholangitis. Anal Cell Pathol (Amst) 2017;2017:7492836

45. Poggi A, Prevosto C, Massaro AM, Negrini S, Urbani S, Pierri I, Saccardi R, Gobbi M, Zocchi MR. Interaction between human NK cells and bone marrow stromal cells induces NK cell triggering: role of NKp30 and NKG2D receptors. J Immunol 2005;175:6352-6360

46. Crop MJ, Korevaar SS, de Kuiper R, IJzermans JN, van Besouw NM, Baan CC, Weimar W, Hoogduijn MJ. Human mesenchymal stem cells are susceptible to lysis by CD8 (+) T cells and NK cells. Cell Transplant 2011;20:15471559

47. Fontaine MJ, Shih H, Schäfer R, Pittenger MF. Unraveling the mesenchymal stromal cells' paracrine immunomodulatory effects. Transfus Med Rev 2016;30:37-43

48. Tamura H. Immunopathogenesis and immunotherapy of multiple myeloma. Int J Hematol 2018;107:278-285

49. Augello A, Tasso R, Negrini SM, Amateis A, Indiveri F, Cancedda R, Pennesi G. Bone marrow mesenchymal progenitor cells inhibit lymphocyte proliferation by activation of the programmed death 1 pathway. Eur J Immunol 2005; 35:1482-1490

50. Corcione A, Benvenuto F, Ferretti E, Giunti D, Cappiello V, Cazzanti F, Risso M, Gualandi F, Mancardi GL, Pistoia V, Uccelli A. Human mesenchymal stem cells modulate B-cell functions. Blood 2006;107:367-372

51. Najar M, Raicevic G, Fayyad-Kazan H, Bron D, Toungouz M, Lagneaux L. Mesenchymal stromal cells and immunomodulation: a gathering of regulatory immune cells. Cytotherapy 2016;18:160-171

52. Tabera S, Pérez-Simón JA, Díez-Campelo M, SánchezAbarca LI, Blanco B, López A, Benito A, Ocio E, SánchezGuijo FM, Cañizo C, San Miguel JF. The effect of mesenchymal stem cells on the viability, proliferation and differentiation of B-lymphocytes. Haematologica 2008;93:13011309

53. Cheng L, Zhang K, Wu S, Cui M, Xu T. Focus on mesenchymal stem cell-derived exosomes: opportunities and challenges in cell-free therapy. Stem Cells Int 2017;2017: 6305295

54. Silva LHA, Antunes MA, Dos Santos CC, Weiss DJ, Cruz FF, Rocco PRM. Strategies to improve the therapeutic effects of mesenchymal stromal cells in respiratory diseases. Stem Cell Res Ther 2018;9:45

55. Hu C, Li L. Preconditioning influences mesenchymal stem cell properties in vitro and in vivo. J Cell Mol Med 2018; 22:1428-1442

56. Orbay H, Tobita M, Mizuno H. Mesenchymal stem cells isolated from adipose and other tissues: basic biological properties and clinical applications. Stem Cells Int 2012; 


\section{2:461718}

57. Chevillet JR, Kang Q, Ruf IK, Briggs HA, Vojtech LN, Hughes SM, Cheng HH, Arroyo JD, Meredith EK, Gallichotte EN, Pogosova-Agadjanyan EL, Morrissey C, Stirewalt DL, Hladik F, Yu EY, Higano CS, Tewari M. Quantitative and stoichiometric analysis of the microRNA content of exosomes. Proc Natl Acad Sci U S A 2014;111: 14888-14893

58. Jang MJ, You D, Park JY, Kim K, Aum J, Lee C, Song G, Shin HC, Suh N, Kim YM, Kim CS. Hypoxic preconditioned mesenchymal stromal cell therapy in a rat model of renal ischemia-reperfusion injury: development of optimal protocol to potentiate therapeutic efficacy. Int J Stem Cells 2018;11:157-167

59. Kheirandish M, Gavgani SP, Samiee S. The effect of hypoxia preconditioning on the neural and stemness genes expression profiling in human umbilical cord blood mesenchymal stem cells. Transfus Apher Sci 2017;56:392-399

60. Saparov A, Ogay V, Nurgozhin T, Jumabay M, Chen WC. Preconditioning of human mesenchymal stem cells to enhance their regulation of the immune response. Stem Cells Int 2016;2016:3924858

61. Kim YS, Noh MY, Cho KA, Kim H, Kwon MS, Kim KS, Kim J, Koh SH, Kim SH. Hypoxia/reoxygenation-preconditioned human bone marrow-derived mesenchymal stromal cells rescue ischemic rat cortical neurons by enhancing trophic factor release. Mol Neurobiol 2015;52:792803

62. Engela AU, Baan CC, Peeters AM, Weimar W, Hoogduijn MJ. Interaction between adipose tissue-derived mesenchymal stem cells and regulatory T-cells. Cell Transplant 2013;22:41-54

63. English K, Tonlorenzi R, Cossu G, Wood KJ. Mesoangioblasts suppress $\mathrm{T}$ cell proliferation through IDO and PGE-2-dependent pathways. Stem Cells Dev 2013;22:512523

64. Lee JH, Yoon YM, Lee SH. Hypoxic preconditioning promotes the bioactivities of mesenchymal stem cells via the HIF-1 $\alpha$-GRP78-Akt axis. Int J Mol Sci 2017;18:E1320

65. Han YS, Lee JH, Yoon YM, Yun CW, Noh H, Lee SH. Hypoxia-induced expression of cellular prion protein improves the therapeutic potential of mesenchymal stem cells. Cell Death Dis 2016;7:e2395

66. Potier E, Ferreira E, Meunier A, Sedel L, Logeart-Avramoglou D, Petite H. Prolonged hypoxia concomitant with serum deprivation induces massive human mesenchymal stem cell death. Tissue Eng 2007;13:1325-1331

67. Deschepper M, Oudina K, David B, Myrtil V, Collet C, Bensidhoum M, Logeart-Avramoglou D, Petite H. Survival and function of mesenchymal stem cells (MSCs) depend on glucose to overcome exposure to long-term, severe and continuous hypoxia. J Cell Mol Med 2011;15:1505-1514

68. Abarbanell AM, Coffey AC, Fehrenbacher JW, Beckman DJ, Herrmann JL, Weil B, Meldrum DR. Proinflammatory cytokine effects on mesenchymal stem cell therapy for the ischemic heart. Ann Thorac Surg 2009;88:1036-1043
69. François M, Romieu-Mourez R, Li M, Galipeau J. Human MSC suppression correlates with cytokine induction of indoleamine 2,3-dioxygenase and bystander M2 macrophage differentiation. Mol Ther 2012;20:187-195

70. Ma S, Xie N, Li W, Yuan B, Shi Y, Wang Y. Immunobiology of mesenchymal stem cells. Cell Death Differ 2014;21: 216-225

71. Carrero R, Cerrada I, Lledó E, Dopazo J, García-García F, Rubio MP, Trigueros C, Dorronsoro A, Ruiz-Sauri A, Montero JA, Sepúlveda P. IL1 $\beta$ induces mesenchymal stem cells migration and leucocyte chemotaxis through NF- $\kappa$ B. Stem Cell Rev 2012;8:905-916

72. Fan H, Zhao G, Liu L, Liu F, Gong W, Liu X, Yang L, Wang J, Hou Y. Pre-treatment with IL-1 $\beta$ enhances the efficacy of MSC transplantation in DSS-induced colitis. Cell Mol Immunol 2012;9:473-481

73. Duijvestein $M$, Wildenberg ME, Welling MM, Hennink S, Molendijk I, van Zuylen VL, Bosse T, Vos AC, de Jonge-Muller ES, Roelofs H, van der Weerd L, Verspaget HW, Fibbe WE, te Velde AA, van den Brink GR, Hommes DW. Pretreatment with interferon- $\gamma$ enhances the therapeutic activity of mesenchymal stromal cells in animal models of colitis. Stem Cells 2011;29:1549-1558

74. Liu X, Duan B, Cheng Z, Jia X, Mao L, Fu H, Che Y, Ou L, Liu L, Kong D. SDF-1/CXCR4 axis modulates bone marrow mesenchymal stem cell apoptosis, migration and cytokine secretion. Protein Cell 2011;2:845-854

75. Linares GR, Chiu CT, Scheuing L, Leng Y, Liao HM, Maric D, Chuang DM. Preconditioning mesenchymal stem cells with the mood stabilizers lithium and valproic acid enhances therapeutic efficacy in a mouse model of Huntington's disease. Exp Neurol 2016;281:81-92

76. Wei N, Yu SP, Gu X, Taylor TM, Song D, Liu XF, Wei L. Delayed intranasal delivery of hypoxic-preconditioned bone marrow mesenchymal stem cells enhanced cell homing and therapeutic benefits after ischemic stroke in mice. Cell Transplant 2013;22:977-991

77. Schäfer R, Spohn G, Baer PC. Mesenchymal stem/stromal cells in regenerative medicine: can preconditioning strategies improve therapeutic efficacy? Transfus Med Hemother 2016;43:256-267

78. Xu X, Zhu F, Zhang M, Zeng D, Luo D, Liu G, Cui W, Wang S, Guo W, Xing W, Liang H, Li L, Fu X, Jiang J, Huang H. Stromal cell-derived factor-1 enhances wound healing through recruiting bone marrow-derived mesenchymal stem cells to the wound area and promoting neovascularization. Cells Tissues Organs 2013;197:103-113

79. Wisel S, Khan M, Kuppusamy ML, Mohan IK, Chacko SM, Rivera BK, Sun BC, Hideg K, Kuppusamy P. Pharmacological preconditioning of mesenchymal stem cells with trimetazidine (1-[2,3,4-trimethoxybenzyl]piperazine) protects hypoxic cells against oxidative stress and enhances recovery of myocardial function in infarcted heart through Bcl-2 expression. J Pharmacol Exp Ther 2009;329:543-550

80. Tsai CC, Yew TL, Yang DC, Huang WH, Hung SC. Benefits of hypoxic culture on bone marrow multipotent 
stromal cells. Am J Blood Res 2012;2:148-159

81. Yao Y, Zhang F, Wang L, Zhang G, Wang Z, Chen J, Gao $\mathrm{X}$. Lipopolysaccharide preconditioning enhances the efficacy of mesenchymal stem cells transplantation in a rat model of acute myocardial infarction. J Biomed Sci 2009; 16:74

82. Cui X, Wang H, Guo H, Wang C, Ao H, Liu X, Tan YZ. Transplantation of mesenchymal stem cells preconditioned with diazoxide, a mitochondrial ATP-sensitive potassium channel opener, promotes repair of myocardial infarction in rats. Tohoku J Exp Med 2010;220:139-147

83. Liu J, Zhu P, Song P, Xiong W, Chen H, Peng W, Wang S, Li S, Fu Z, Wang Y, Wang H. Pretreatment of adipose derived stem cells with curcumin facilitates myocardial recovery via antiapoptosis and angiogenesis. Stem Cells Int 2015;2015:638153

84. Bhatti FU, Mehmood A, Latief N, Zahra S, Cho H, Khan SN, Riazuddin S. Vitamin E protects rat mesenchymal stem cells against hydrogen peroxide-induced oxidative stress in vitro and improves their therapeutic potential in surgically-induced rat model of osteoarthritis. Osteoarthritis Cartilage 2017;25:321-331

85. Qiao PF, Yao L, Zhang XC, Li GD, Wu DQ. Heat shock pretreatment improves stem cell repair following ischemia-reperfusion injury via autophagy. World J Gastroenterol 2015;21:12822-12834

86. Chen X, Wang Q, Li X, Wang Q, Xie J, Fu X. Heat shock pretreatment of mesenchymal stem cells for inhibiting the apoptosis of ovarian granulosa cells enhanced the repair effect on chemotherapy-induced premature ovarian failure. Stem Cell Res Ther 2018;9:240

87. Hoogduijn MJ, de Witte SF, Luk F, van den Hout-van Vroonhoven MC, Ignatowicz L, Catar R, Strini T, Korevaar SS, van IJcken WF, Betjes MG, Franquesa M, Moll G, Baan CC. Effects of freeze-thawing and intravenous infusion on mesenchymal stromal cell gene expression. Stem Cells Dev 2016;25:586-597

88. Chinnadurai R, Copland IB, Garcia MA, Petersen CT, Lewis CN, Waller EK, Kirk AD, Galipeau J. Cryopreserved mesenchymal stromal cells are susceptible to T-cell mediated apoptosis which is partly rescued by IFN $\gamma$ licensing. Stem Cells 2016;34:2429-2442

89. Pawitan JA. Prospect of stem cell conditioned medium in regenerative medicine. Biomed Res Int 2014;2014:965849

90. Chang CP, Chio CC, Cheong CU, Chao CM, Cheng BC, Lin MT. Hypoxic preconditioning enhances the therapeutic potential of the secretome from cultured human mesenchymal stem cells in experimental traumatic brain injury. Clin Sci (Lond) 2013;124:165-176

91. Arutyunyan I, Fatkhudinov T, Kananykhina E, Usman N, Elchaninov A, Makarov A, Bolshakova G, Goldshtein D, Sukhikh G. Role of VEGF-A in angiogenesis promoted by umbilical cord-derived mesenchymal stromal/stem cells: in vitro study. Stem Cell Res Ther 2016;7:46

92. Sriramulu S, Banerjee A, Di Liddo R, Jothimani G, Gopinath M, Murugesan R, Marotta F, Pathak S. Concise review on clinical applications of conditioned medium derived from human umbilical cord-mesenchymal stem cells (UC-MSCs). Int J Hematol Oncol Stem Cell Res 2018;12: 230-234

93. Gama KB, Santos DS, Evangelista AF, Silva DN, de Alcântara AC, Dos Santos RR, Soares MBP, Villarreal CF. Conditioned medium of bone marrow-derived mesenchymal stromal cells as a therapeutic approach to neuropathic pain: a preclinical evaluation. Stem Cells Int 2018;2018: 8179013

94. Kay AG, Long G, Tyler G, Stefan A, Broadfoot SJ, Piccinini AM, Middleton J, Kehoe O. Mesenchymal stem cell-conditioned medium reduces disease severity and immune responses in inflammatory arthritis. Sci Rep 2017;7:18019

95. Hwang B, Liles WC, Waworuntu R, Mulligan MS. Pretreatment with bone marrow-derived mesenchymal stromal cell-conditioned media confers pulmonary ischemic tolerance. J Thorac Cardiovasc Surg 2016;151:841-849

96. Timmers L, Lim SK, Hoefer IE, Arslan F, Lai RC, van Oorschot AA, Goumans MJ, Strijder C, Sze SK, Choo A, Piek JJ, Doevendans PA, Pasterkamp G, de Kleijn DP. Human mesenchymal stem cell-conditioned medium improves cardiac function following myocardial infarction. Stem Cell Res 2011;6:206-214

97. Xu X, Li D, Li X, Shi Q, Ju X. Mesenchymal stem cell conditioned medium alleviates oxidative stress injury induced by hydrogen peroxide via regulating miR143 and its target protein in hepatocytes. BMC Immunol 2017;18:51

98. Kadekar D, Rangole S, Kale V, Limaye L. Conditioned medium from placental mesenchymal stem cells reduces oxidative stress during the cryopreservation of ex vivo expanded umbilical cord blood cells. PLoS One 2016;11: $\mathrm{e} 016546$

99. Lai RC, Yeo RW, Lim SK. Mesenchymal stem cell exosomes. Semin Cell Dev Biol 2015;40:82-88

100. Lai RC, Chen TS, Lim SK. Mesenchymal stem cell exosome: a novel stem cell-based therapy for cardiovascular disease. Regen Med 2011;6:481-492

101. Phinney DG, Pittenger MF. Concise review: MSC-derived exosomes for cell-free therapy. Stem Cells 2017;35:851-858

102. Breitbach M, Bostani T, Roell W, Xia Y, Dewald O, Nygren JM, Fries JW, Tiemann K, Bohlen H, Hescheler J, Welz A, Bloch W, Jacobsen SE, Fleischmann BK. Potential risks of bone marrow cell transplantation into infarcted hearts. Blood 2007;110:1362-1369

103. Furlani D, Ugurlucan M, Ong L, Bieback K, Pittermann E, Westien I, Wang W, Yerebakan C, Li W, Gaebel R, Li RK, Vollmar B, Steinhoff G, Ma N. Is the intravascular administration of mesenchymal stem cells safe? Mesenchymal stem cells and intravital microscopy. Microvasc Res 2009;77:370-376

104. Poh KK, Sperry E, Young RG, Freyman T, Barringhaus $\mathrm{KG}$, Thompson CA. Repeated direct endomyocardial transplantation of allogeneic mesenchymal stem cells: safety of a high dose, "off-the-shelf", cellular cardiomyoplasty strategy. Int J Cardiol 2007;117:360-364 
105. Lou G, Chen Z, Zheng M, Liu Y. Mesenchymal stem cell-derived exosomes as a new therapeutic strategy for liver diseases. Exp Mol Med 2017;49:e346

106. Ghidoni R, Paterlini A, Albertini V, Glionna M, Monti E, Schiaffonati L, Benussi L, Levy E, Binetti G. Cystatin C is released in association with exosomes: a new tool of neuronal communication which is unbalanced in Alzheimer's disease. Neurobiol Aging 2011;32:1435-1442

107. Putz U, Howitt J, Lackovic J, Foot N, Kumar S, Silke J, Tan SS. Nedd4 family-interacting protein 1 (Ndfipl) is required for the exosomal secretion of Nedd4 family proteins. J Biol Chem 2008;283:32621-32627

108. Huang JH, Yin XM, Xu Y, Xu CC, Lin X, Ye FB, Cao $\mathrm{Y}$, Lin FY. Systemic administration of exosomes released from mesenchymal stromal cells attenuates apoptosis, inflammation, and promotes angiogenesis after spinal cord injury in rats. J Neurotrauma 2017;34:3388-3396

109. Cosenza S, Ruiz M, Toupet K, Jorgensen C, Noël D. Mesenchymal stem cells derived exosomes and microparticles protect cartilage and bone from degradation in osteoarthritis. Sci Rep 2017;7:16214

110. Cha JM, Shin EK, Sung JH, Moon GJ, Kim EH, Cho YH, Park HD, Bae H, Kim J, Bang OY. Efficient scalable production of therapeutic microvesicles derived from human mesenchymal stem cells. Sci Rep 2018;8:1171

111. Biancone L, Bruno S, Deregibus MC, Tetta C, Camussi G. Therapeutic potential of mesenchymal stem cell-derived microvesicles. Nephrol Dial Transplant 2012;27:3037-3042

112. Chen W, Huang Y, Han J, Yu L, Li Y, Lu Z, Li H, Liu Z, Shi C, Duan F, Xiao Y. Immunomodulatory effects of mesenchymal stromal cells-derived exosome. Immunol Res 2016;64:831-840

113. Mokarizadeh A, Delirezh N, Morshedi A, Mosayebi G, Farshid AA, Mardani K. Microvesicles derived from mesenchymal stem cells: potent organelles for induction of tolerogenic signaling. Immunol Lett 2012;147:47-54

114. Wang $\mathrm{H}$, Zheng $\mathrm{R}$, Chen Q, Shao J, Yu J, Hu S. Mesenchymal stem cells microvesicles stabilize endothelial barrier function partly mediated by hepatocyte growth factor (HGF). Stem Cell Res Ther 2017;8:211

115. Ji Y, Ma Y, Chen X, Ji X, Gao J, Zhang L, Ye K, Qiao F, Dai Y, Wang H, Wen X, Lin J, Hu J. Microvesicles released from human embryonic stem cell derived-mesenchymal stem cells inhibit proliferation of leukemia cells. Oncol Rep 2017;38:1013-1020

116. Monsel A, Zhu YG, Gennai S, Hao Q, Hu S, Rouby JJ, Rosenzwajg M, Matthay MA, Lee JW. Therapeutic effects of human mesenchymal stem cell-derived microvesicles in severe pneumonia in mice. Am J Respir Crit Care Med 2015;192:324-336

117. Bruno S, Grange C, Deregibus MC, Calogero RA, Saviozzi S, Collino F, Morando L, Busca A, Falda M, Bussolati B, Tetta C, Camussi G. Mesenchymal stem cell-derived microvesicles protect against acute tubular injury. J Am Soc Nephrol 2009;20:1053-1067

118. Liu D, Kou X, Chen C, Liu S, Liu Y, Yu W, Yu T, Yang
R, Wang R, Zhou Y, Shi S. Circulating apoptotic bodies maintain mesenchymal stem cell homeostasis and ameliorate osteopenia via transferring multiple cellular factors. Cell Res 2018;28:918-933

119. Abreu SC, Weiss DJ, Rocco PR. Extracellular vesicles derived from mesenchymal stromal cells: a therapeutic option in respiratory diseases? Stem Cell Res Ther 2016;7:53

120. Merino-González C, Zuñiga FA, Escudero C, Ormazabal V, Reyes C, Nova-Lamperti E, Salomón C, Aguayo C. Mesenchymal stem cell-derived extracellular vesicles promote angiogenesis: potencial clinical application. Front Physiol 2016;7:24

121. Penberthy KK, Ravichandran KS. Apoptotic cell recognition receptors and scavenger receptors. Immunol Rev 2016;269:44-59

122. Eslaminejad MB, Fani N, Shahhoseini M. Epigenetic regulation of osteogenic and chondrogenic differentiation of mesenchymal stem cells in culture. Cell J 2013;15:1-10

123. Huang B, Li G, Jiang XH. Fate determination in mesenchymal stem cells: a perspective from histone-modifying enzymes. Stem Cell Res Ther 2015;6:35

124. Xing Y, Hou J, Guo T, Zheng S, Zhou C, Huang H, Chen Y, Sun K, Zhong T, Wang J, Li H, Wang T. microRNA378 promotes mesenchymal stem cell survival and vascularization under hypoxic-ischemic conditions in vitro. Stem Cell Res Ther 2014;5:130

125. Chang YH, Wu KC, Harn HJ, Lin SZ, Ding DC. Exosomes and stem cells in degenerative disease diagnosis and therapy. Cell Transplant 2018;27:349-363

126. Griffin M, Greiser U, Barry F, O'Brien T, Ritter T. Genetically modified mesenchymal stem cells and their clinical potential in acute cardiovascular disease. Discov Med 2010;9:219-223

127. Wang W, Xu X, Li Z, Lendlein A, Ma N. Genetic engineering of mesenchymal stem cells by non-viral gene delivery. Clin Hemorheol Microcirc 2014;58:19-48

128. Yau TM, Fung K, Weisel RD, Fujii T, Mickle DA, Li RK. Enhanced myocardial angiogenesis by gene transfer with transplanted cells. Circulation 2001;104(12 Suppl 1):I218I 222

129. Hodgkinson CP, Gomez JA, Mirotsou M, Dzau VJ. Genetic engineering of mesenchymal stem cells and its application in human disease therapy. Hum Gene Ther 2010;21:15131526

130. Jo J, Nagaya N, Miyahara Y, Kataoka M, Harada-Shiba M, Kangawa K, Tabata Y. Transplantation of genetically engineered mesenchymal stem cells improves cardiac function in rats with myocardial infarction: benefit of a novel nonviral vector, cationized dextran. Tissue Eng 2007;13: 313-322

131. Wyse RD, Dunbar GL, Rossignol J. Use of genetically modified mesenchymal stem cells to treat neurodegenerative diseases. Int J Mol Sci 2014;15:1719-1745

132. Zhang Z, Deb A, Zhang Z, Pachori A, He W, Guo J, Pratt R, Dzau VJ. Secreted frizzled related protein 2 protects cells from apoptosis by blocking the effect of canonical 
Wnt3a. J Mol Cell Cardiol 2009;46:370-377

133. Chen SL, Zhu CC, Liu YQ, Tang LJ, Yi L, Yu BJ, Wang DJ. Mesenchymal stem cells genetically modified with the angiopoietin-1 gene enhanced arteriogenesis in a porcine model of chronic myocardial ischaemia. J Int Med Res 2009;37:68-78

134. Huang J, Zhang Z, Guo J, Ni A, Deb A, Zhang L, Mirotsou M, Pratt RE, Dzau VJ. Genetic modification of mesenchymal stem cells overexpressing CCR1 increases cell viability, migration, engraftment, and capillary density in the injured myocardium. Circ Res 2010;106:1753-1762

135. Wang M, Tan J, Wang Y, Meldrum KK, Dinarello CA, Meldrum DR. IL-18 binding protein-expressing mesenchymal stem cells improve myocardial protection after ischemia or infarction. Proc Natl Acad Sci U S A 2009;106: 17499-17504

136. Nakamura K, Ito Y, Kawano Y, Kurozumi K, Kobune M, Tsuda H, Bizen A, Honmou O, Niitsu Y, Hamada H. Antitumor effect of genetically engineered mesenchymal stem cells in a rat glioma model. Gene Ther 2004;11:11551164

137. Maestroni GJ, Hertens E, Galli P. Factor(s) from nonmacrophage bone marrow stromal cells inhibit Lewis lung carcinoma and B16 melanoma growth in mice. Cell Mol Life Sci 1999;55:663-667

138. Xu XP, Huang LL, Hu SL, Han JB, He HL, Xu JY, Xie JF, Liu AR, Liu SQ, Liu L, Huang YZ, Guo FM, Yang Y, Qiu HB. Genetic modification of mesenchymal stem cells overexpressing angiotensin II type 2 receptor increases cell migration to injured lung in LPS-induced acute lung injury mice. Stem Cells Transl Med 2018;7:721730

139. Dos Santos Picanco LC, Ozela PF, de Fatima de Brito Brito M, Pinheiro AA, Padilha EC, Braga FS, de Paula da Silva CHT, Dos Santos CBR, Rosa JMC, da Silva HageMelim LI. Alzheimer's disease: a review from the pathophysiology to diagnosis, new perspectives for pharmacological treatment. Curr Med Chem 2018;25:3141-3159

140. Mroczko B, Groblewska M, Litman-Zawadzka A, Kornhuber J, Lewczuk P. Cellular receptors of amyloid $\beta$ oligomers (A $\beta$ Os) in Alzheimer's disease. Int J Mol Sci 2018;19: E1884

141. Zheng JJ, Li WX, Liu JQ, Guo YC, Wang Q, Li GH, Dai SX, Huang JF. Low expression of aging-related NRXN3 is associated with Alzheimer disease: a systematic review and meta-analysis. Medicine (Baltimore) 2018;97:e11343

142. Salem AM, Ahmed HH, Atta HM, Ghazy MA, Aglan HA. Potential of bone marrow mesenchymal stem cells in management of Alzheimer's disease in female rats. Cell Biol Int 2014;38:1367-1383

143. Bali P, Lahiri DK, Banik A, Nehru B, Anand A. Potential for stem cells therapy in Alzheimer's disease: do neurotrophic factors play critical role? Curr Alzheimer Res 2017; 14:208-220

144. Libro R, Diomede F, Scionti D, Piattelli A, Grassi G, Pollastro F, Bramanti P, Mazzon E, Trubiani O. Cannabi- diol modulates the expression of Alzheimer's disease-related genes in mesenchymal stem cells. Int J Mol Sci 2016; 18:E26

145. Cui GH, Wu J, Mou FF, Xie WH, Wang FB, Wang QL, Fang J, Xu YW, Dong YR, Liu JR, Guo HD. Exosomes derived from hypoxia-preconditioned mesenchymal stromal cells ameliorate cognitive decline by rescuing synaptic dysfunction and regulating inflammatory responses in APP/PS1 mice. FASEB J 2018;32:654-668

146. Park SE, Lee J, Chang EH, Kim JH, Sung JH, Na DL, Chang JW. Activin A secreted by human mesenchymal stem cells induces neuronal development and neurite outgrowth in an in vitro model of Alzheimer's disease: neurogenesis induced by MSCs via activin A. Arch Pharm Res 2016;39:1171-1179

147. Kim DH, Lee D, Chang EH, Kim JH, Hwang JW, Kim JY, Kyung JW, Kim SH, Oh JS, Shim SM, Na DL, Oh W, Chang JW. GDF-15 secreted from human umbilical cord blood mesenchymal stem cells delivered through the cerebrospinal fluid promotes hippocampal neurogenesis and synaptic activity in an Alzheimer's disease model. Stem Cells Dev 2015;24:2378-2390

148. Lee JK, Schuchman EH, Jin HK, Bae JS. Soluble CCL5 derived from bone marrow-derived mesenchymal stem cells and activated by amyloid $\beta$ ameliorates Alzheimer's disease in mice by recruiting bone marrow-induced microglia immune responses. Stem Cells 2012;30:1544-1555

149. Kim JY, Kim DH, Kim JH, Lee D, Jeon HB, Kwon SJ, Kim SM, Yoo YJ, Lee EH, Choi SJ, Seo SW, Lee JI, Na DL, Yang YS, Oh W, Chang JW. Soluble intracellular adhesion molecule-1 secreted by human umbilical cord blood-derived mesenchymal stem cell reduces amyloid- $\beta$ plaques. Cell Death Differ 2012;19:680-691

150. Lee NK, Park SE, Kwon SJ, Shim S, Byeon Y, Kim JH, Na DL, Chang JW. Agouti related peptide secreted via human mesenchymal stem cells upregulates proteasome activity in an Alzheimer's disease model. Sci Rep 2017;7: 39340

151. Kim DH, Lim H, Lee D, Choi SJ, Oh W, Yang YS, Oh JS, Hwang HH, Jeon HB. Thrombospondin-1 secreted by human umbilical cord blood-derived mesenchymal stem cells rescues neurons from synaptic dysfunction in Alzheimer's disease model. Sci Rep 2018;8:354

152. Oh SH, Kim HN, Park HJ, Shin JY, Lee PH. Mesenchymal stem cells increase hippocampal neurogenesis and neuronal differentiation by enhancing the Wnt signaling pathway in an Alzheimer's disease model. Cell Transplant 2015; 24:1097-1109

153. Liew LC, Katsuda T, Gailhouste L, Nakagama H, Ochiya T. Mesenchymal stem cell-derived extracellular vesicles: a glimmer of hope in treating Alzheimer's disease. Int Immunol 2017;29:11-19

154. Liu Z, Wang C, Wang X, Xu S. Therapeutic effects of transplantation of as-miR-937-expressing mesenchymal stem cells in murine model of Alzheimer's disease. Cell Physiol Biochem 2015;37:321-330 
155. Tan XF, Qin JB, Jin GH, Tian ML, Li HM, Zhu HX, Zhang XH, Shi JH, Huang Z. Effects of Brn-4 on the neuronal differentiation of neural stem cells derived from rat midbrain. Cell Biol Int 2010;34:877-882

156. Li G, Peskind ER, Millard SP, Chi P, Sokal I, Yu CE, Bekris LM, Raskind MA, Galasko DR, Montine TJ. Cerebrospinal fluid concentration of brain-derived neurotrophic factor and cognitive function in non-demented subjects. PLoS One 2009;4:e5424

157. Song MS, Learman CR, Ahn KC, Baker GB, Kippe J, Field EM, Dunbar GL. In vitro validation of effects of BDNFexpressing mesenchymal stem cells on neurodegeneration in primary cultured neurons of APP/PS1 mice. Neuroscience 2015;307:37-50

158. Avanzino L, Lagravinese G, Abbruzzese G, Pelosin E. Relationships between gait and emotion in Parkinson's disease: a narrative review. Gait Posture 2018;65:57-64

159. Kalia LV, Lang AE. Parkinson's disease. Lancet 2015;386: 896-912

160. Spillantini MG, Schmidt ML, Lee VM, Trojanowski JQ, Jakes R, Goedert M. Alpha-synuclein in Lewy bodies. Nature 1997;388:839-840

161. Stoker TB, Barker RA. Regenerative therapies for Parkinson's disease: an update. BioDrugs 2018;32:357-366

162. Lekishvili T, Hesketh S, Brazier MW, Brown DR. Mouse galectin-1 inhibits the toxicity of glutamate by modifying NR1 NMDA receptor expression. Eur J Neurosci 2006;24: 3017-3025

163. Oh SH, Kim HN, Park HJ, Shin JY, Bae EJ, Sunwoo MK, Lee SJ, Lee PH. Mesenchymal stem cells inhibit transmission of $\alpha$-synuclein by modulating clathrin-mediated endocytosis in a Parkinsonian model. Cell Rep 2016;14: 835-849

164. Wang Y, Yang J, Li H, Wang X, Zhu L, Fan M, Wang $\mathrm{X}$. Hypoxia promotes dopaminergic differentiation of mesenchymal stem cells and shows benefits for transplantation in a rat model of Parkinson's disease. PLoS One 2013;8: e54296

165. Jinfeng L, Yunliang W, Xinshan L, Yutong W, Shanshan W, Peng X, Xiaopeng Y, Zhixiu X, Qingshan L, Honglei Y, Xia C, Hongwei W, Bingzhen C. Therapeutic effects of CUR-activated human umbilical cord mesenchymal stem cells on 1-methyl-4-phenylpyridine-induced Parkinson's disease cell model. Biomed Res Int 2016;2016:9140541

166. Chierchia A, Chirico N, Boeri L, Raimondi I, Riva GA, Raimondi MT, Tunesi M, Giordano C, Forloni G, Albani D. Secretome released from hydrogel-embedded adipose mesenchymal stem cells protects against the Parkinson's disease related toxin 6-hydroxydopamine. Eur J Pharm Biopharm 2017;121:113-120

167. Yao Y, Huang C, Gu P, Wen T. Combined MSC-secreted factors and neural stem cell transplantation promote functional recovery of PD rats. Cell Transplant 2016;25:11011113

168. Mei J, Niu C. Effects of engineered conserved dopamine neurotrophic factor-expressing bone marrow stromal cells on dopaminergic neurons following 6-OHDA administrations. Mol Med Rep 2015;11:1207-1213

169. Moradian H, Keshvari H, Fasehee H, Dinarvand R, Faghihi S. Combining NT3-overexpressing MSCs and PLGA microcarriers for brain tissue engineering: a potential tool for treatment of Parkinson's disease. Mater Sci Eng C Mater Biol Appl 2017;76:934-943

170. Barzilay R, Ben-Zur T, Bulvik S, Melamed E, Offen D. Lentiviral delivery of LMXla enhances dopaminergic phenotype in differentiated human bone marrow mesenchymal stem cells. Stem Cells Dev 2009;18:591-601

171. Liu XS, Li JF, Wang SS, Wang YT, Zhang YZ, Yin HL, Geng S, Gong HC, Han B, Wang YL. Human umbilical cord mesenchymal stem cells infected with adenovirus expressing HGF promote regeneration of damaged neuron cells in a Parkinson's disease model. Biomed Res Int 2014; 2014:909657

172. Ghosh R, Tabrizi SJ. Clinical features of Huntington's disease. Adv Exp Med Biol 2018;1049:1-28

173. Pandey M, Rajamma U. Huntington's disease: the coming of age. J Genet 2018;97:649-664

174. Joyce N, Annett G, Wirthlin L, Olson S, Bauer G, Nolta JA. Mesenchymal stem cells for the treatment of neurodegenerative disease. Regen Med 2010;5:933-946

175. Fink KD, Rossignol J, Crane AT, Davis KK, Bombard MC, Bavar AM, Clerc S, Lowrance SA, Song C, Lescaudron L, Dunbar GL. Transplantation of umbilical cord-derived mesenchymal stem cells into the striata of R6/2 mice: behavioral and neuropathological analysis. Stem Cell Res Ther 2013;4:130

176. Rossignol J, Fink K, Davis K, Clerc S, Crane A, Matchynski J, Lowrance S, Bombard M, Dekorver N, Lescaudron L, Dunbar GL. Transplants of adult mesenchymal and neural stem cells provide neuroprotection and behavioral sparing in a transgenic rat model of Huntington's disease. Stem Cells 2014;32:500-509

177. Sadan O, Shemesh N, Barzilay R, Dadon-Nahum M, Blumenfeld-Katzir T, Assaf Y, Yeshurun M, Djaldetti R, Cohen Y, Melamed E, Offen D. Mesenchymal stem cells induced to secrete neurotrophic factors attenuate quinolinic acid toxicity: a potential therapy for Huntington's disease. Exp Neurol 2012;234:417-427

178. Lin YT, Chern Y, Shen CK, Wen HL, Chang YC, Li H, Cheng TH, Hsieh-Li HM. Human mesenchymal stem cells prolong survival and ameliorate motor deficit through trophic support in Huntington's disease mouse models. PLoS One 2011;6:e22924

179. Olson SD, Kambal A, Pollock K, Mitchell GM, Stewart H, Kalomoiris S, Cary W, Nacey C, Pepper K, Nolta JA. Examination of mesenchymal stem cell-mediated RNAi transfer to Huntington's disease affected neuronal cells for reduction of huntingtin. Mol Cell Neurosci 2012;49:271281

180. Dey ND, Bombard MC, Roland BP, Davidson S, Lu M, Rossignol J, Sandstrom MI, Skeel RL, Lescaudron L, Dunbar GL. Genetically engineered mesenchymal stem 
cells reduce behavioral deficits in the YAC 128 mouse model of Huntington's disease. Behav Brain Res 2010;214: 193-200

181. Olson SD, Pollock K, Kambal A, Cary W, Mitchell GM, Tempkin J, Stewart H, McGee J, Bauer G, Kim HS,
Tempkin T, Wheelock V, Annett G, Dunbar G, Nolta JA. Genetically engineered mesenchymal stem cells as a proposed therapeutic for Huntington's disease. Mol Neurobiol 2012;45:87-98 